\title{
The Role of Rituals in the Design and Planning of Green Spaces - A Case Study: Tehran and the Persian New Year
}

\author{
Sanaz Shobeiri \\ School of Architecture and the Built Environment, University of Westminster, United Kingdom
}

Copyright@2019 by authors, all rights reserved. Authors agree that this article remains permanently open access under the terms of the Creative Commons Attribution License 4.0 International License

\begin{abstract}
One of the current global challenges in landscape urbanism is how to ensure that cultural attitudes and preferences are reflected in the design and planning. The rituals that take place in each cultural context contribute to social and cultural interactions and connectivity with nature. Despite the continuity of some cultural traditions, other rituals have been weakened throughout history and need to be strengthened, revived, or revitalized. This paper investigates the aforementioned aspects of rituals associated with the Persian New Year and their interrelation with Tehran's natural structures, and in particular the river valleys. The study will be two-fold. First, it aims to familiarize both international and Iranian readers with the existing and fading traditions related to the Persian New Year. Second, the paper studies the characteristics of a particular context from users' points of view in order to present the specific traditions of this key annual event. For the main conclusion, this paper will consider the integrated whole of human nature - or, more precisely, culture-nature - regarding the Persian New Year. The applied methodology consists of a review of the literature and an appropriate comparative analysis (in the first part), along with direct observation, interviews, and design practice (in the second part).
\end{abstract}

Keywords Rituals, Persian New Year, Traditions, Green Spaces, Flowing Water, Nature

\section{Introduction}

The rituals of specific celebratory days in each society stem mostly from its cultural, historical, religious, and moral background; in other words, rituals mainly retell the stories of a nation's distinguishing characteristics, such as its cultural, historical, religious, or moral beliefs. Because of the complexity of the multiple subcultures that exist in any given place, it is difficult or even impossible to determine the precise boundaries of cultural regions and, therefore, one should conceptualize gradations, rather than fixed boundaries, between cultural regions. Furthermore, while the history of some of these specific celebratory days can be traced to the ancient world, others have actually been developed in recent years [1-6].

In the Iranian-Tehranian context, there are two distinct and sometimes divergent facets to analyze. On the one hand, Iranian history has a direct lineage to ancient worlds and civilizations, while on the other, Tehran has only been recognized as a city since 1524 , and as the country's capital since 1794. The city only started to develop around 500 years ago (to be more precise, 494 years ago) and, as a result, the current observable customs and traditions in the Iranian-Tehranian context could be the outcomes of different levels of change over time, both on the scale of the country and on that of the city [7-10].

The first part of this paper focuses on the present, most important annual festive occasion, the Persian New Year. The history of this event can be traced back to ancient civilizations; it has also been chronologically affected in the Iranian-Tehranian context. Some traditions of this annual event have remained unchanged or implemented with only slight changes each year by the 13-million-strong population that makes up the province of Tehran, as of 2017, while other rituals associated with this annual event have been strongly affected over time. As a result, some rites of the Persian New Year have partially or completely disappeared through the ages, while others remain in place [7-12].

The traditions associated with this annual cultural-historical event occupy different levels on a spectrum of existence-disappearance. The first part of this paper will investigate the chronological changes of the rituals associated with the Persian New Year to uncover two aspects that exist but need to be strengthened and developed, and those that are disappearing or hidden, and 
therefore need to be revived.

The second part of this paper will investigate the characteristics of suitable areas for the rituals that are an integral part of this annual event. In other words, this part will examine the features that make an area suitable to keep, strengthen, and revive the customs and traditions associated with the Persian New Year. To do so, this paper will look at the characteristics of the present-day areas that are deemed suitable, as well as the features of potential and desired green spaces. These existing and potential characteristics are analyzed on a large scale, with the main focus being their relevance to the fields of urban design and planning. This paper's focus on the Persian New Year and its nature-based events enables a complementary and sequential investigation to further the possibility of socio-cultural sustainability in the Iranian-Tehranian context.

\section{Methodology}

\subsection{Literature Review and Related Analysis}

As explained above, the paper consists of two main parts. The first studies the chronological background of the events associated with the Persian New Year; to this end, the main method applied is a literature review and related analysis. A critical evaluation will also be carried out by revising and updating the literature review for different stages of each aspect of this research. This will give rise to in-depth information on the context and background of the study; the paper will encompass a review of the literature, with a particular focus on the antecedents of the Persian New Year. Reviewing the literature is also helpful as it allows us to better focus the topic of inquiry, understand the make-up of the research question, and delineate the current conceptual landscape $[13,14]$.

\subsection{Direct Observation}

The second part of this paper examines the characteristics of suitable areas to host the rites, traditions, and customs associated with the nature-based events of the Persian New Year, including both the existing as well as the potential and desired features. To this end, two methods of direct observation and interviews have been applied: direct appraisals will investigate the visible and existing aspects of the Persian New Year, while a series of interviews will focus on users' hidden likes and dislikes, preferences, and desires in terms of suitable areas for these specific days.

In 2013, Gehl and Svarre [15] explained the notion of direct observation in the following way:

As a general rule, users are not actively involved in the sense of being questioned, rather they are observed, their activities and behavior mapped in order to better understand the needs of users and how city spaces are used ... [In direct observation,] people's behavior is documented, analyzed and interpreted, but this is not done under the microscope. The observations are conducted with the naked eyes and occasionally using cameras or other aids to zoom in on situations or fast-freeze the moment in order to analyze the situation more closely. The point is to sharpen the gaze of the observer ... Watching with care and attention [in direct observation] is precisely what it takes to wrest useful knowledge from ordinary scenes [15, pp. 3, 5].

Direct observation is applied in this research to look at the natural settings and non-interfered status of the current ways the rituals associated with the Persian New Year are implemented.

Such a study of the customs and traditions of the nature-based events of the Persian New Year through direct observation gives rise to questions regarding whether the present areas available for the pertinent rituals meet Tehranians' needs and preferences. In other words, there is concern as to whether the existing ways in which Tehranians are able to celebrate the Persian New Year are based on their genuine desires, or whether people have simply adapted to the available options because these are the only opportunities they are currently able to access. As a result, direct observation is necessary; however, it is not a sufficient means by which to establish the characteristics of a suitable and desired area for these specific events from the user's point of view. Thus, direct observation needs to be accompanied by another method that enables the researcher to study the hidden but potential aspects of Tehranians' preferences concerning this annual event.

\subsection{Interviews}

The primary method used to study the above-mentioned invisible aspects is the semi-structured interview. As explained by Galletta [16] in 2013, "a key benefit of the semi-structured interview is its attention to lived experience while also addressing theoretically driven variables of interest" [16, p.24]. In this research, the semi-structured interviews will examine the extent to which the existing options for celebrating the Persian New Year are based on Tehranians' genuine preferences. In order to do so, 130 interviews were carried out in two types of natural area in urban and peri-urban areas of Tehran: linear parks and mountainous recreational areas situated in a neighborhood featuring a number of rivers. The interviews were mainly carried out in the winter, spring and summer of 2013, between the hours of 10 a.m.-2 p.m. and 6 p.m. -1 a.m.

In order to select an appropriate number of case studies for the interviews, it was necessary to consider all main types of project implemented in the river neighborhood, which included linear parks and mountainous areas; this point is explained in detail in the following sections of this 
paper. Although the interview questions investigate Tehranians' interactions with the natural structures of Tehran, particularly with river-valleys in a general context, the differences between linear parks and mountainous areas have resulted in dissimilar perceptions of this natural structure in these two types of area. As a result, it was necessary to perform one case study for each of these two areas in the river neighborhoods. A linear park called Nahj-ol-Balagheh and a mountainous recreational area called Darband were selected as suitable locations to find participants for the interviews. This approach also provided an opportunity for a comparison between linear parks and mountainous areas in terms of users' latent likes, dislikes, and preferences.

A pilot study of 25 interviews conducted in the summer and autumn of 2012 and the winter of 2013 in the Darband mountainous recreational area and Nahj-ol-Balagheh showed that the types of user vary according to the season and time. The pilot study revealed that there were two key groups of users in Darband and three major groups in Nahj-ol-Balagheh. In this study, the predefined minimum number of interviews for each group of users was 20 persons, and when this number was reached, the interview process was stopped, and other groups of interviewees were considered. This clarifies the approximate ratio of user groups, and hence reveals the minor and major groups of users.

Sixty interviews were carried out in the Darband mountainous recreational area, based on two groups of people. The first included 20 people who were neighbors or who lived at a distance of less than 15 minutes by vehicle or walking from the area, while the second included 40 people who lived further than 15 minutes or more by vehicle or walking from the area. Seventy interviews were carried out at Nahj-ol-Balagheh in the Farahzad river-valley, divided into three groups of respondents. The first group included 25 neighbors and people from distances of less than 15 minutes by vehicle or walking, while the second consisted of 25 people whose main daily activities took place in the neighborhood of the park. Students and staff members of a university located close to the park are exemplified here to clarify this point. The third group was made up of 20 people traveling distances of 15 minutes or more by vehicle or walking. All 130 interviewees were frequent users of these areas and were interviewed on site while carrying out their usual and preferred activities.

It should be noted that the overall findings of these interviewee groups need to be considered based on the required scale of research; in other words, the detailed answers need to be generalized so they can be extended to the scale of the city and Tehranian citizens as a whole.

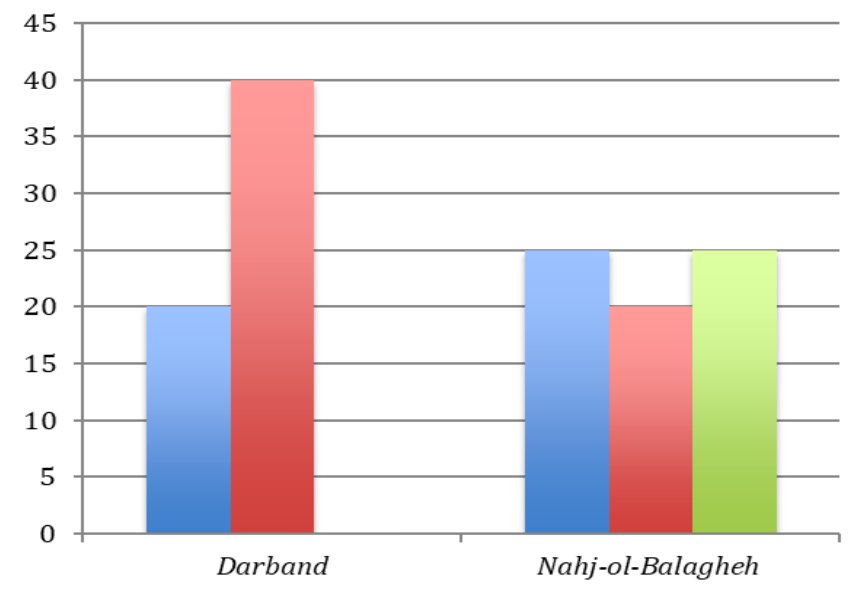

= neighbors and less than 15 minutes of distance

= 15 minutes and more of distance

- Because of neighborhood activities

Figure 1. Groups and number of interviews at the survey sites used for this research (Source: Author, 2013) 


\subsection{Design and Planning}

After the first two parts of the study, the final step of this paper will be to re-integrate the findings with the practice. In other words, after investigating the rituals of the Persian New Year and the characteristics of a suitable area in the Iranian-Tehranian context, this paper will integrate the findings as they pertain to the design and planning. In this paper, design is a key part of the process of analysis; in action research, it plays a fundamental role in the final sections, such as the propositions and the design and planning on the scale of the city. Subsequently, and in a more coherent sense, design in collaboration with the context and the environment forms the whole reasoning behind this paper, which integrates an analysis of the social and cultural context with the natural landscape in the country's most important annual festival, the Persian New Year.

As Wang [13] explained in 2002, "Research is a more legitimate form of scholarly inquiry than design ... [and as a result,] efforts should be made to encourage the view that design activity and research activity are of equal value" [13, p.107]. The concepts of design as analysis and evaluation, as action research, and in collaboration with the context and environment, as explained by Wang [13], further clarify the role of design as a method of conducting research. In summary, combined consideration of the design, context, and environment forms the main logical background of this paper.

\section{Part One: The Persian New Year}

\subsection{Norouz ${ }^{1}$ and Mitrakan (Mehregan)}

Before explaining the water-based ceremonies that are a feature of Iranian culture, it should be noted that, at present, Norouz $^{2}$ is identified as the Iranian New Year, taking place at the spring equinox. However, in the ancient world of Iran, the New Year was not recognized as Norouz; rather, Norouz was the celebration of the spring equinox and, according to the Persian calendar, the New Year occurred at another time of the year. As explained by Razi [2] in 2004, at the time of the Achaemenid Empire (550-330 $\mathrm{BCE}$ ), one of the most important dynasties of Iran, the Persian New Year was first held at the time of the autumn equinox and was known as Mitrakan or Mehregan. Later, as a result of the cooperation and agreement between multiple groups with various religious beliefs, an eclectic calendar $^{3}$ was created and, based on this calendar, the

1 This is also written as Nowruz, Nowrouz, Navruz, Nawruz, Nevruz, Nourooz, and Norooz $[2,19,20]$

2 The start of Norouz and the first day of the month Farvardin in the Persian calendar is equivalent to March 20-21. For more detail, please see [18, pp.177-179]

3 The main calendar in Iran, which was originally formed at the time of
Persian New Year was transferred to the spring equinox $[1,2,17]$.

Norouz, as the start of spring, entailing specific customs and traditions, became celebrated more widely later, in particular at the time of the Sassanid ${ }^{4}$ Empire (224-651 $C E^{5}$ ). In the literature of ancient Iran, two key celebrations are noted: Norouz, the start of spring, and Mehregan, the Persian New Year. In other words, although the New Year celebration was transferred from the autumn to the spring equinox at the time of the Sassanid Empire, Mehregan with its Zoroastrianism ${ }^{6}$-based customs and traditions was still followed as strongly as before.

Daniel and Mahdi [18] explained this in 2006 as follows:

Nowruz is one of the most celebrated and important Iranian holidays. It is observed not only in Iran but also in Azerbaijan, central Asia, Afghanistan, Pakistan, parts of India, and among the Kurds ... It is also an important time for renewing social relationships and putting households and financial matters in order. People clean up their houses, buy new clothing and furniture, and often hope for a new beginning ... Children, employees, and various acquaintances also expect to receive a cash gift ' $i d i$ ' for the New Year. Nowruz is a very joyous time, with lots of special foods, visits to friends and relatives, performances by street entertainers, and so forth [18, pp.186-187].

Norouz, the biggest national celebration of the start of spring, has special customs and traditions, all of which are dependent on or related to nature. In other words, the traditions of Norouz explicitly or metaphorically represent Iranians' affinity, beliefs, and respect for nature. One of these traditions is the preparation of a special table setting, called "Haft Sin." This custom has been held since the time of the Sassanid Empire [2,18], and is discussed in more detail in the following sections.

the Sassanid Empire, is termed "Shamsi” (the Iranian solar calendar). This calendar has been modified and revised over time, and in the present format - also known as the Jalali calendar - there are 12 months: Farvardin, Ordibehesht, Khordad, Tir, Mordad, Shahrivar, Mehr, Aban, Azar, Dey, Bahman, and Esfand. The year starts at the exact moment of the vernal equinox. The first six months have 31 days, while the next five months have 30, and the last month, Esfand, can have either 29 or 30 days. In order to clarify the differences and also the relationship between the Shamsi and Gregorian calendars, one example is provided here. 01 Farvardin 1394 (first day of Norouz in the Shamsi calendar) is equivalent to March 21, 215. For more detail. please see [18, pp.177-179]. It is worth noting that the Zoroastrian Sassanid, also known as the Sassanian Empire (224-651 CE), fell to the Arab Islamic invasion in $651 \mathrm{CE}$, but the Shamsi calendar that was formed in $621 \mathrm{CE}$ has remained the main calendar of Iran up to the present day [1,2,31,32].

4 Sassanid, also known as the Sassanian Empire, fell to the Arab Islamic invasion in $651 \mathrm{CE}$ [31].

5 This is also mentioned as 226-651 [48].

6 It is important to note many different viewpoints have been put forward by key scholars about the religion of the Achaemenid Empire in Iran. Although they are generally identified as Zoroastrians, according to well-known Iranian scholars such as Hashem Razi and Abd-ol-Hossein Zarrinkoob, the Achaemeneids (550-330 BCE) were not Zoroastrians; however, they believed in Ahura Mazda. According to these scholars, Achaemenids were "Non-Zoroastrian Mazda Parast.” Zoroastrianism was propagated throughout Iran at the time of the Sassanid Empire in order to create unity. (For more detail, please see $[1,2,4,5]$. 


\subsection{Norouz and Haft Sin}

One of the most important aspects of Norouz is the preparation of the Haft Sin table. This was described by Daniel and Mahdi [18] in 2006:

The central event of the Nowruz holiday is the laying out of the sofreh, a special holiday tableau on New Year's Eve. Iranians take great pride in the perception of the sofreh, a practice that is rich in tradition, meaning and symbolism. By custom, this consists of an especially attractive dining cloth spread out on the floor (or in more recent, somewhat Westernized usage, a table) and decorated with the haft $\sin ,{ }^{7}$ seven objects whose names in Persian all begin with the letter s. There is some variation in the choice of the haft sin, and there may in fact be more than seven $s$ objects on display [18, p.187].

The most commonly used objects in Haft Sin are sabzeh (sprouted seeds of grain), samanu (a kind of paste made from minced green wheat, oil, almonds, and other ingredients), sib (apple), serkeh (vinegar), sir (fresh garlic), sekkeh (coins), sonbol (hyacinth), somagh (sumac, a sour berry used in Persian cuisine), and senjed (oleaster, or jujubes fruits). Other, lesser-known $s$ objects are siah-daneh (a fennel flower), sepand (seeds of wild rue that are placed in a dish and burned, due to a common belief that this will bring good luck), and sabzi (green herbs). The sofreh should also have a mirror, the Koran (Quran) or other scared or valued books, ${ }^{8}$ lighted candles, a goldfish in a bowl, and colored eggs that have been specially cooked and dyed [1,2,18-20].

Most of the objects on the sofreh are meant to represent the earth and its place in the cosmos, the particular auspiciousness of the moment of the vernal equinox, charms for good fortune and the warding off of evil, the forces of rebirth and regeneration, and the good things in life that one hopes to enjoy over the coming year [18, p.187].

In other words, the items used in the sofreh Haft Sin represent health, happiness, prosperity, fertility, long life, love, joy, production, nature, and light $[19,20]$. It is worth noting that the water and sabzeh in the sofreh Haft Sin are two of the main important items that pertain to the happiness of the Fravahars, the spirits of known family members and friends who have passed away. People believe that ensuring the happiness of the Frahavars will bring blessings in the New Year [2,6]. The sabzeh items are further explained in the following section about the day of Sizdah-be-Dar.

7 "Haft" in Persian means "seven" and "Sin" is the 15th letter of the Persian alphabet, equal to "s" in English.

8 Examples of the holy books are the Quran, the Bible, the Zoroastrian Avesta, the Persian epic poem of Shahnameh by Ferdowsi, or the collection of poetry by the well-known Iranian poet Hafez $[18,20]$.
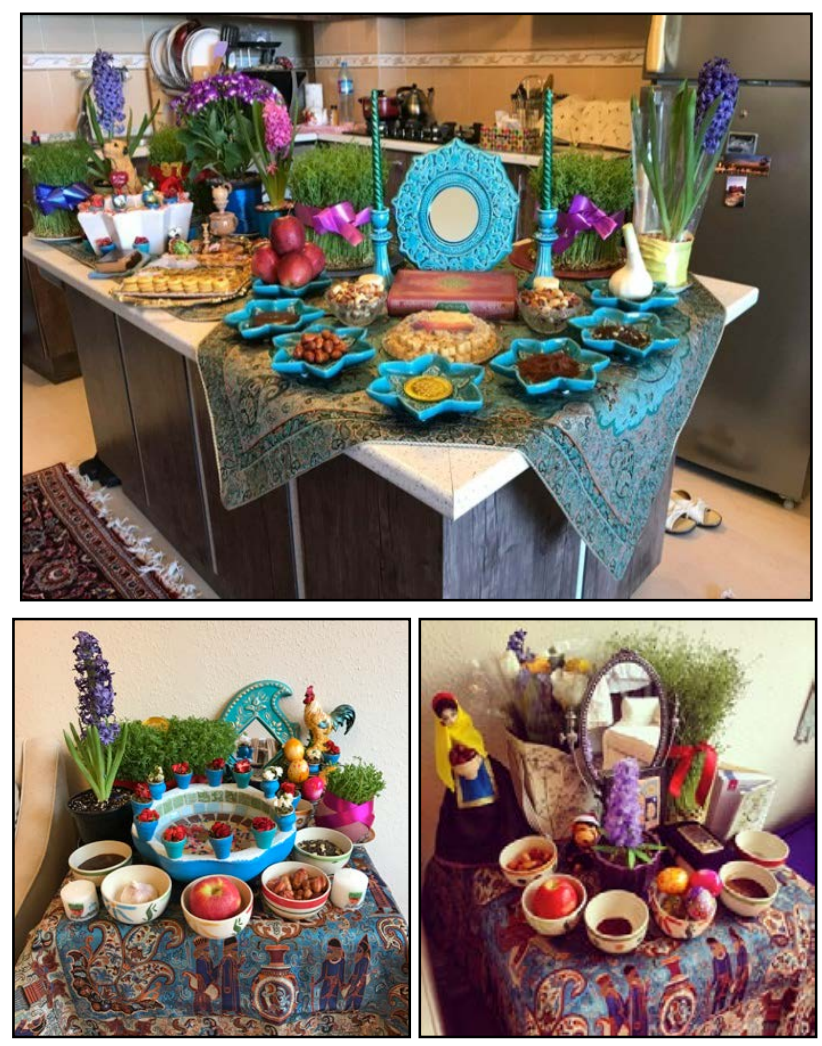

Figure 2. An example of a sofreh Haft Sin (Source: Author, 2016-2018)

\subsection{Small Norouz, Big Norouz, and Ab Pashan}

In present-day Iran, Norouz is celebrated over 13 days, with specific customs and traditions on the final day, which is called Sizdah-be-Dar. Two days previously associated with Norouz that have since disappeared are Big Norouz (Khasseh) and Small Norouz (Aammeh ${ }^{9}$ ). Big Norouz was held on the sixth day of the month of Farvardin, which was believed to be the holy day of the birth of the Zoroaster, while Small Norouz was the first day of the month of Farvardin. According to ancient Iranian literature, during the first five days of Norouz, the king dedicated himself to issues that affected the general public and different classes of society, while Big Norouz was allocated to celebrations in the royal family $[1,2]$.

The sixth day was also associated with the goddess of water protection, which led to the specific customs and traditions of sprinkling water (Ab Pashan ${ }^{10)}$ and ablutions in the water of springs and wells, performed on the sixth day. However, the customs of the sixth day have gradually weakened, and now no longer exist. This could be due to the advent and development of Islam in Iran, at the time of the Sassanid Empire (224-651 CE), when

9 "Khasseh" in Persian means that something has been allocated to a special group, while the term "Aammeh" means that it has been allocated to the general public [49].

10 The term "ab" in Persian means "water" and "pashan" means "sprinkling;” hence “Ab Pashan” means “sprinkling water” [49]. 
Zoroastrian-based beliefs began to fade; the sixth day of Farvardin, as the holy birthday of Zoroaster, was thus deemed less significant $[1,2]$.

\subsection{The 13th Day of Norouz: Ab Rizgan, Tirgan, and Sizdah-be-Dar}

At present, Norouz is a 13-day celebration in Iran. It starts on the first day of the month called Farvardin, ${ }^{11}$ and the last day - the $13^{\text {th }}$ day of Norouz and Farvardin - is called Sizdah-be-Dar. In the Persian language, "Sizdah" means 13, "be" means "to," and "dar" means "door," and therefore Sizdah-be-Dar means "staying outside the door." According to a variety of existing resources, the term "dar" here has two meanings. The first is the door of the city, so Sizdah-be-Dar means staying outside the doors (gates) of a ramparted city, inside nature. Although this was meaningful in the ancient world, the demolition of city walls that took place in the last century means that the term is interpreted to mean staying outside the doors of houses; in other words, it means spending time outdoors, whether within the city or in the countryside [4,9].

The number 13 was considered sinister and wicked in ancient Iranian civilization and Zoroastrianism. Since the beginning of the Nourouz tradition, the $13^{\text {th }}$ day of each new Iranian year is called Sizdah-be-Dar, and this tradition is still alive among Iranian people, both within Iran and abroad. Since Sizdah-be-Dar is the $13^{\text {th }}$ day of the year, it is considered a day when the power of evil might cause people difficulties, and therefore people leave urban areas for the day, and camp in the countryside ... this tradition continues to be practiced by the majority of the population throughout Iran [21, p.23].

Every year on the $13^{\text {th }}$ day of Farvardin, Iranians spend time outdoors with their extended families to eat, sleep, sing, and dance the day away, performing the favorite Iranian pastime of picnicking.

As explained by Massoudi [19] in 2014:

... as with many cultures, the number 13 is considered inauspicious, so this occasion, the 13th day of the New Year, is an opportunity to bypass the perils and pitfalls of daily life. Folks while their time away in the safety of nature, far from the malevolent reach of evil spirits, in a tradition called Sizdah be Dar, or 'Thirteen Undone'. This ancient custom marks the close of Nowrouz festivities and the end of the holidays [19, p.42].

The effect of Zoroastrianism is conspicuous in the symbolism of the day's rituals. However, the present-day Islamic government accepts the rituals by declaring the day as a celebration of nature ("Nature Day"), rather than

11 The start of Norouz and the first days of the month called "Farvardin" in the Persian calendar is equivalent to the March 20 or 21. acknowledging a pre-Islamic rite [18,19,22].
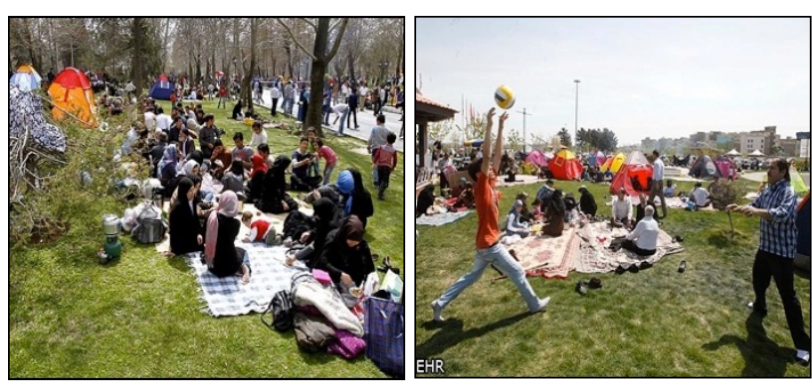

Figure 3. Spending time outdoors on the day of Sizdah-be-Dar (Source of the left image: Ref. [23]; Source of the right image: Ref. [24])

\subsection{Sizdah-be-Dar and the Custom of Placing/Throwing sabzeh in Flowing Water}

One of the most famous customs of the day of Sizdah-be-Dar is placing sabzeh ${ }^{12}$ into flowing water such as rivers and streams. In other words, sabzeh is taken from the sofreh Haft Sin and thrown into running water, such as a river or stream $[2,6,19]$.

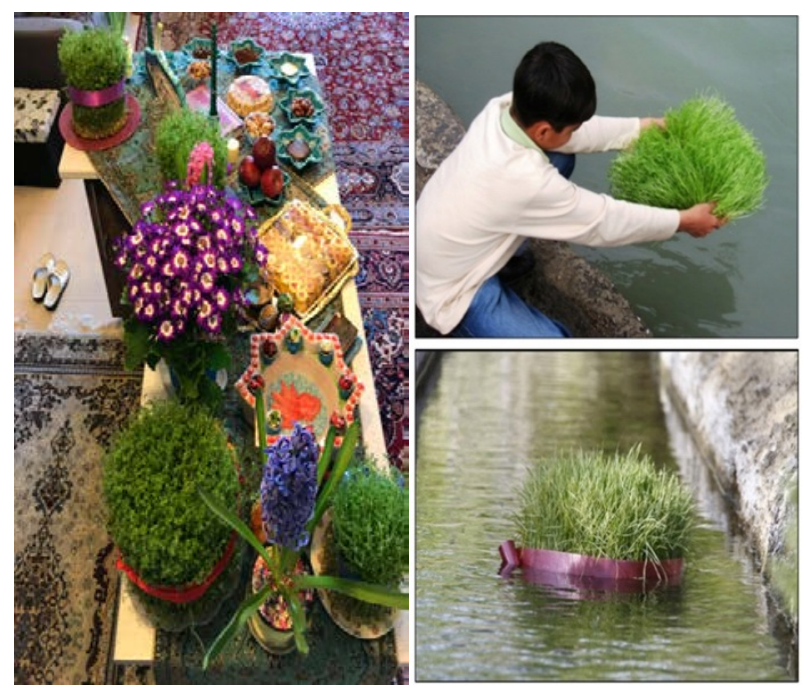

Figure 4. The sabzeh on the sofreh Haft Sin, and throwing or placing it into flowing water on the day of Sizdah-be-Dar (Source of the left image: Author, 2018; Source of the top-right image: Ref. [25]; Source of the bottom-right image: Ref. [26])

\subsubsection{The First Story Related to the Custom of Placing the sabzeh in Flowing Water}

There are two stories that purport to explain the origins of this tradition. The first, which is more well known, stems from the civilization of Mesopotamia and later in the Middle East. According to one myth from Babylonia and the Assur (Ashur) civilization, Tammuz was the god of plant growth and liveliness; this was a terrestrial god who had close relations to agriculture and animal husbandry. Tammuz married Ishtar, the goddess of water, love, and

12 Germinated seeds and green sprouts. 
fertility. According to this myth, Tammuz dies each year due to Ishtar's anger and exasperation, and he goes into the soil, which represents the world of the deceased. His death results in the beginning of summer and the death of all plants due to drought. This is because, in Mesopotamia, the torrid weather that occurred in summer sometimes spoiled agricultural products [2,5,27].

This is interpreted as the death of nature, necessitating a new season of re-growth and fertility; to this end, Ishtar travels to the world of the deceased to bring back her husband, spring, and all plants. Life is thereby brought back to nature at the beginning of spring, and this re-birth is celebrated [2,5,27]. Linguistically, Ishtar is closely related to Anahita, the ancient Persian goddess of water, and it can therefore be said that the more well-known story about this custom concerns the love and life of Ishtar, the feminine goddess of love, fertility and production, and Tammuz, the god of plant growth, agriculture, and life $[2,19,28]$.

It is worth mentioning that, in the old Persian calendar, each day of a month had a specific name. The $13^{\text {th }}$ day was called Tir, as was the fourth month of the year (also the first month of summer), and Tirgan was the $13^{\text {th }}$ day of the month of Tir. The changes that took place in the Persian calendar in the ancient world meant that the specific celebrations in Tirgan were transferred to the $13^{\text {th }}$ day of Norouz, Sizdah-be-Dar. At this time, the reconciliation of Ishtar and Tammuz was mainly celebrated on the $13^{\text {th }}$ day of the month, Tir, and hence in the early days of summer. Although this reconciliation was identified as the start of spring and the rebirth of nature, the rituals of Tirgan, and particularly Ab Rizgan, were mainly held in early summer (in Tirgan) in order for people to ask for rain, as an imitative magic and simulative allegory.

As explained by Razi [1] in 2003, Ab Rizgan included the rituals of the day of Tirgan. " $A b$ " in Persian means "water," while "Rizgan" means "pouring” or "sprinkling." In ancient Iran, the day of Tirgan was home to a tradition of performing ablutions and pouring the water of rivers, springs, and streams [1,2,29]. Furthermore, by considering the literal meanings and relation between the words "Ishtar" ${ }^{13}$ and "Tirgan," we can clarify the correlation between the day of Sizdah-be-Dar and the ancient story of Ishtar and Tammuz. The custom of placing sabzeh in running water is a symbol of the reconciliation of Ishtar and Tammuz. Although the story behind this tradition is unknown by a significant number of Iranians, the custom remains in place and is observed by a majority of Iranians each year on Sizdah-be-Dar [2,29].

\subsubsection{The Second Story Related to the Custom of Placing sabzeh in Flowing Water}

The second story about the custom of placing sabzeh in running water concerns the feminine guardian angel-goddess of water, called Anahita. Her name in mentioned in various sources related to Indo-Iran from 3,000 BCE $[1,6,30]$. Nabarz [31] touched on this further in 2013:

The name Anahita is still used for girls in Iran, and in recent decades ... has been gaining in popularity. This being so, the link to Anahita from about 3,000 years ago is still alive today in Iranian culture, and is not limited to the domain of history books ... Anahita's full title is Aredvi Sura Anahita, which means 'moist', 'mighty', and 'immaculate' (pure) ... Anahita is an Indo-Iranian Mother Goddess [who] ... has been linked to the goddess Ishtar' [31, p.1].

\section{In Persian mythology, Anahita is the:}

goddess of all the waters upon the earth and the source of the cosmic ocean; she drives a chariot pulled by four horses: wind, rain, cloud, and sleet; her symbol is the eight-rayed star. She is regarded as the source of life ... Because of her connection with life, warriors in battle prayed to her for survival and victory [31, p.97].

According to the second story about Sizdah-be-Dar, on this day, Anahita was locked in combat with the devil of drought. Because she was successful, her victory is celebrated each year by people who spend time outdoors in natural and green areas, especially near rivers or other types of running water. Placing the sabzeh in the flowing water of a river is a symbolic custom to appreciate Anahita because her victory over draught resulted in the return of spring to the earth. As already explained, whether or not people are familiar with the story, Iranians still follow the custom of placing sabzeh in running water, and it is still a key custom of Sizdah-be-Dar. This custom is also known for killing bad luck and ill omens that might occur on that day, and also any unpleasant events throughout the year $[1,2,5,33]$.

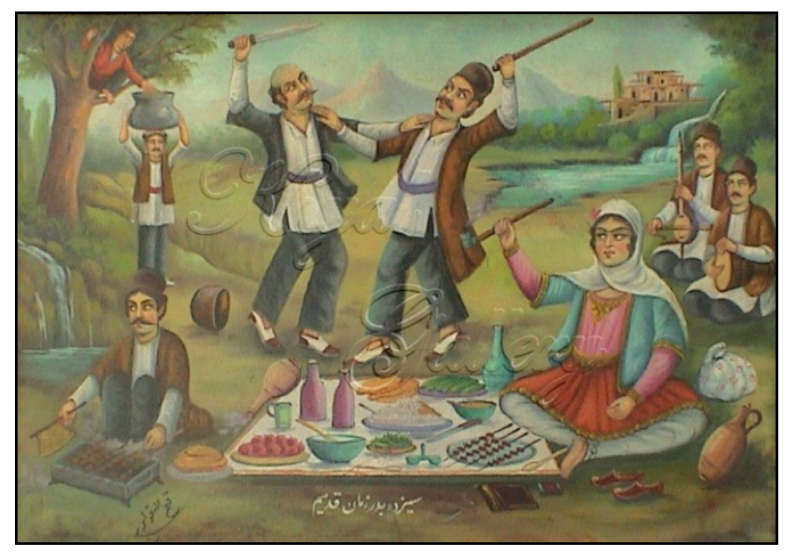

Figure 5. The day of Sizdah-be-Dar in ancient Iran; painting by Fathollah Gholar (Source: Ref. [34]) 


\subsection{Sizdah-be-Dar and the Custom of Tying Two Pieces of Grass Together}

Another custom that is common for Sizdah-be-Dar is the tying together of two pieces of grass. This tradition metaphorically retells the love story of Ishtar and Tammuz, and "Single girls do this in the hope that they are married by the end of the year" [19, p.42]. In other words, tying a knot between green shoots is a symbol of the marriage knot, as young women tie grass in knots and wish for a good husband and a successful marriage by the end of the year $[19,2,28]$.

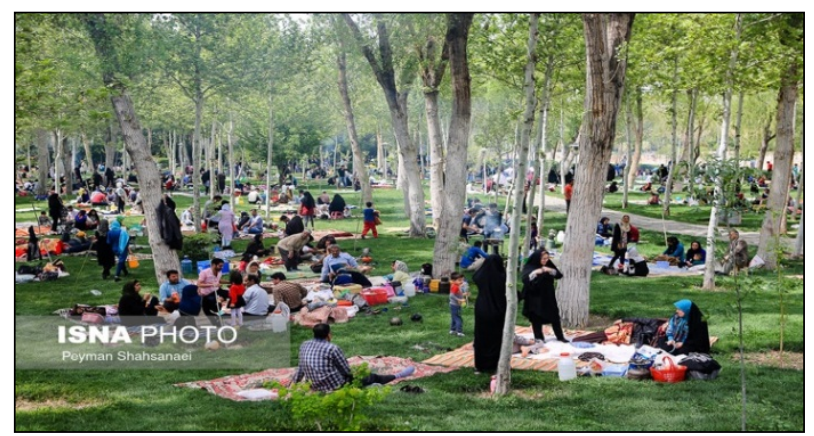

Figure 6. The day of Sizdah-be-Dar in present-day Iran (Source: Ref. [35])

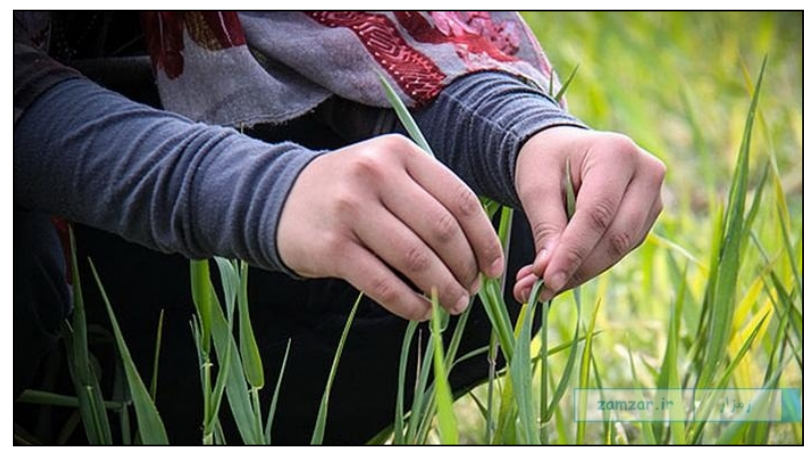

Figure 7. Sizdah-be-Dar and the custom of tying two pieces of grass together (Source: Ref. [36])

Daniel and Mahdi (2006) go into further detail about this:

... the idea is that 13 is an unlucky number, and any quarrels or problems on that day portend misfortune for the whole year. Everyone should thus try to ward off the bad luck by having as good a time as possible, traditionally by spending the day outdoors on a picnic in a park or open area (always a popular activity with most Iranians). Traditional foods for the occasion vary in different regions and among various ethnic groups. However, many consume a noodle soup ${ }^{14}$ and lettuce leaves soaked in a homemade syrup called Sekanjebin (a mixture of sugar and vinegar). It is also customary to dispose the sprouts used for the sofreh on this day, the

14 Known as “ash-e-reshteh,” a thick vegetable soup. last formality of the New Year's celebration. The task is often assigned to young unmarried girls; in a more general practice suggestive of fertility aspects of the New Year's celebration, they may also tie together blades of grass (p.188).

Up to this point, this paper has mainly addressed the Persian New Year and its water-based events such as Norouz and Mitrakan (Mehregan); Norouz and Haft Sin; Small Norouz, Big Norouz, and Ab Pashan; and the 13th day of Norouz, encompassing Ab Rizgan, Tirgan, and Sizdah-be-Dar. The latter and its most common customs and traditions such as placing sabzeh in flowing water and tying two pieces of grass together are also explained. In contemporary urban Iran, however, the only remaining festival and traditions take place on the day of Sizdah-be-Dar, but some Iranian-Tehranians have begun to revive the other annual rituals that had previously faded in popularity. These two points were confirmed in this research through direct observation and interviews. The second part of this paper will discuss this tendency and the characteristics of areas of the city that, from Tehranians' point of view, are suitable to keep, revive, and strengthen the nature-based rites associated with this annual event.

\section{Part Two: The Tendency of Tehranians to Keep and Revive New Year Rituals, and the Characteristics of Suitable Areas for the Rites of This Annual Event}

Direct observation of the Iranian-Tehranian context shows that, at present, Tehranians preserve the annual event of Sizdah-be-Dar and eagerly look forward to performing these customs and traditions. Furthermore, the interviews revealed that Tehranians are not only interested in keeping and strengthening existing rituals, but also favor reviving forgotten, weakened, and disappearing aspects of history. As the majority of the interviewees explained, by reviving disappearing facets of history, Iranians can bring back hidden aspects of their identity. The interview process investigated the characteristics of a suitable context that, from the locals' point of view, aids the continuation of specific customs and traditions, both existing and faded.

The interviews confirmed the contemporary tendency to keep customs and traditions alive. A green space must have specific characteristics in order to render it suitable for these rituals, and these required characteristics were described by the majority of interviewees, as shown in the following section.

From the perspective of the 130 interviewees, key factors that make an area suitable for specific days such as Sizdah-be-Dar are the extent to which it is open and natural, the degree of greenness, vastness, and openness (such as open and flat green spaces with wilderness aspects), access to flowing water such as rivers and streams, the amount of 
space and privacy available for each family (the feeling of not being overcrowded), ease of access and the presence of few or no traffic problems, and a sense of general calmness and peace in the area.

The need to have access to flowing water such as rivers and streams, and the presence of open and flat green spaces with connotations of wilderness, are related to the traditions of placing sabzeh in flowing water and the tying of two pieces of grass together, as explained previously in this paper. As a result, in order to specify suitable areas that offer these two characteristics in urban and peri-urban areas of Tehran, it is necessary to grasp the flowing water and topography of Tehran.

\subsection{The Context: Tehran}

Tehran has been the capital of Iran since 1794. Since then, it has experienced three historical eras: the Qajar dynasty (1794-1925), the Pahlavi dynasty (1925-1979), and the Islamic Republic (1979-present). During these years, the entire area of the city has undergone constant development. The structural and spatial changes to Tehran, in particular since the city became the capital, have resulted in the transformation of an enclosed city; its population has exploded from 15,000 in 1794 to a provincial total of 13 million in 2017, as it has developed into an ever-growing megalopolis [7-12]. It would be beyond the scope of this paper to outline the full details of all dynasties and related events of all the kings of Iran; however, the following diagrams describe in more detail the key dynasties and kings who promoted changes to Tehran, and the central points in the process of the city's development and expansion.

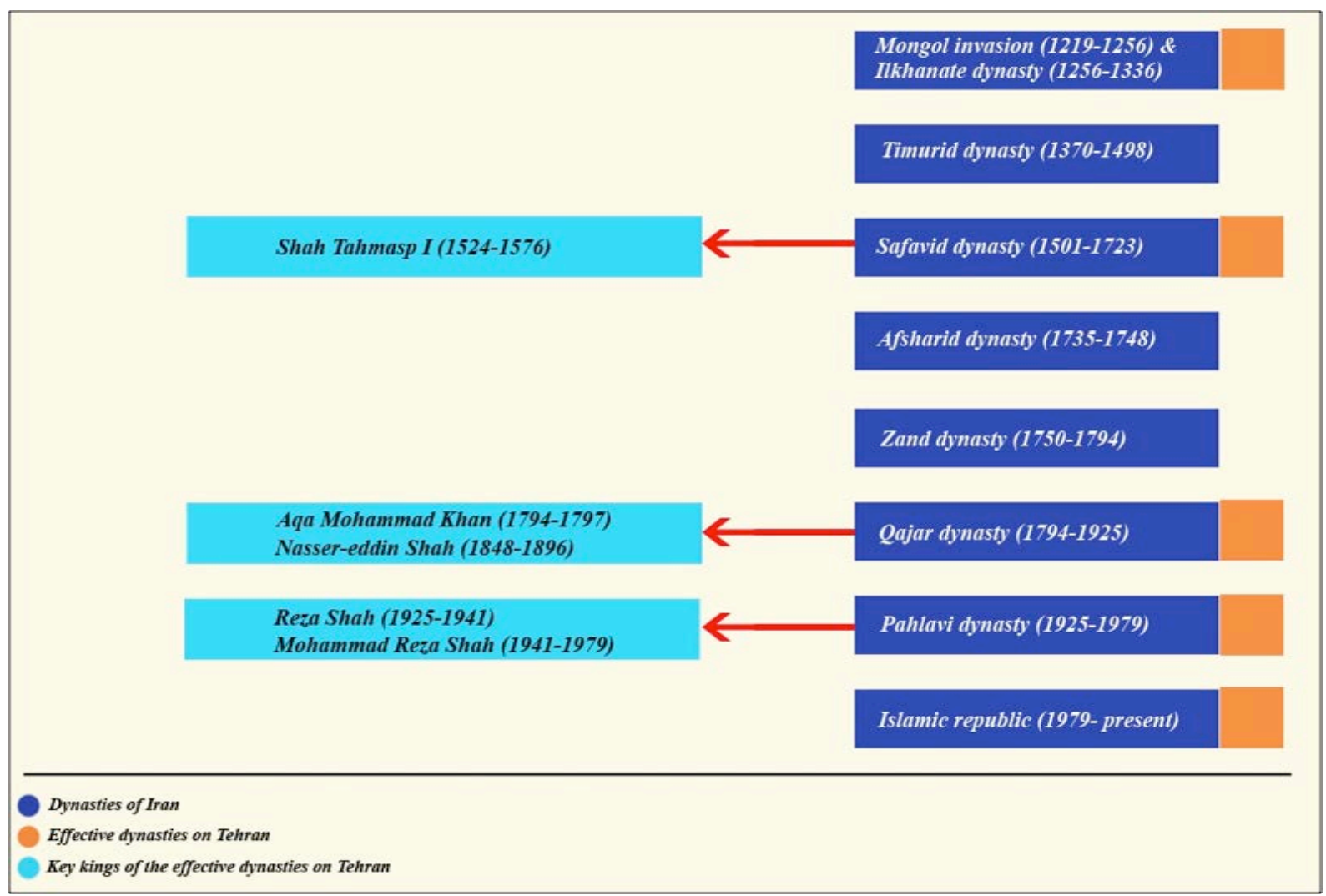

Figure 8. The most relevant dynasties and kings in the process of change in Tehran (Source: Author 2016). (The sources for this diagram are Refs. [7-10,37-39]. It should be noted that, during the Afsharid and Zand dynasties, minor changes were made to various resources. However, the most important dates are mentioned in the diagram.) 
Tehran as a village:

Tehran before and during the Mongol invasion (1219-1256)

(Tehran until 14th century)

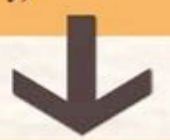

Tehran becoming a city:

Tehran during the Safavid dynasty (1501-1723) in particular in the time of the Shah Tahmasp I (1524-1576)-

(Tehran in 1524-1723)

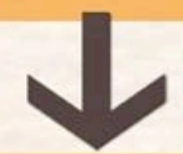

The city of Tehran becoming the capital:

from Aqa Mohammad Khan Qajar (1794- 1797) to

Nasser-eddin Shah Qajar (1848-1896)-

(Tehran in 1794-1848)

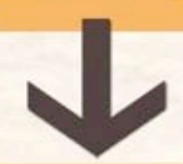

Tehran as an expanding capital with new walls:

Tehran from the time of Nasser-eddin Shah Qajar (1848-1896) to the end of the Qajar dynasty (1925)(Tehran in 1848-19251)

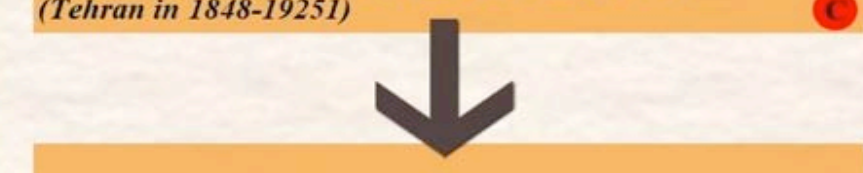

Tehran as the capital without surrounding walls:

Tehran in the time of Reza Shah Pahlavi (1925-1941)

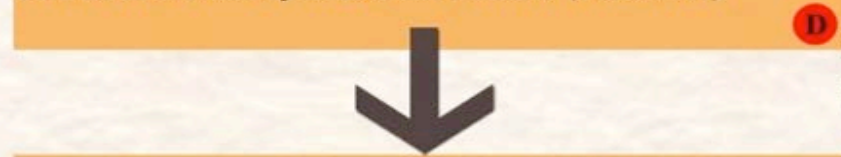

Tehran as an excessive expanding city becoming

a metropolis or megalopolis:

Tehran since Mohammad Reza Shah Pahlavi (1941-1979)-

(Tehran since 1941)

Figure 9. Tehran and its developments and expansion (Source of the maps: Refs. [8,9]; Source of the applied dates: Refs. [7-10,37-39])

\subsection{The topography of Tehran}

Geographically, Tehran occupies a special position. Located on the southern slopes of the Alborz mountain range, the city has rich resources of water and a mild climate. The slopes of the Alborz provide natural protection against the heat and dryness of the southern deserts. The height difference between the northernmost and southernmost areas of the city is around one kilometer. Across this range of height in the north-south direction, the city is made up of three sections: mountain, foothills (hillsides), and plain lands. Although the height decreases in the north-south direction, there is also a semi-mountainous area in the southeast area of Tehran, called the Bibi Shahr Banoo Mountain $[8,40]$. 


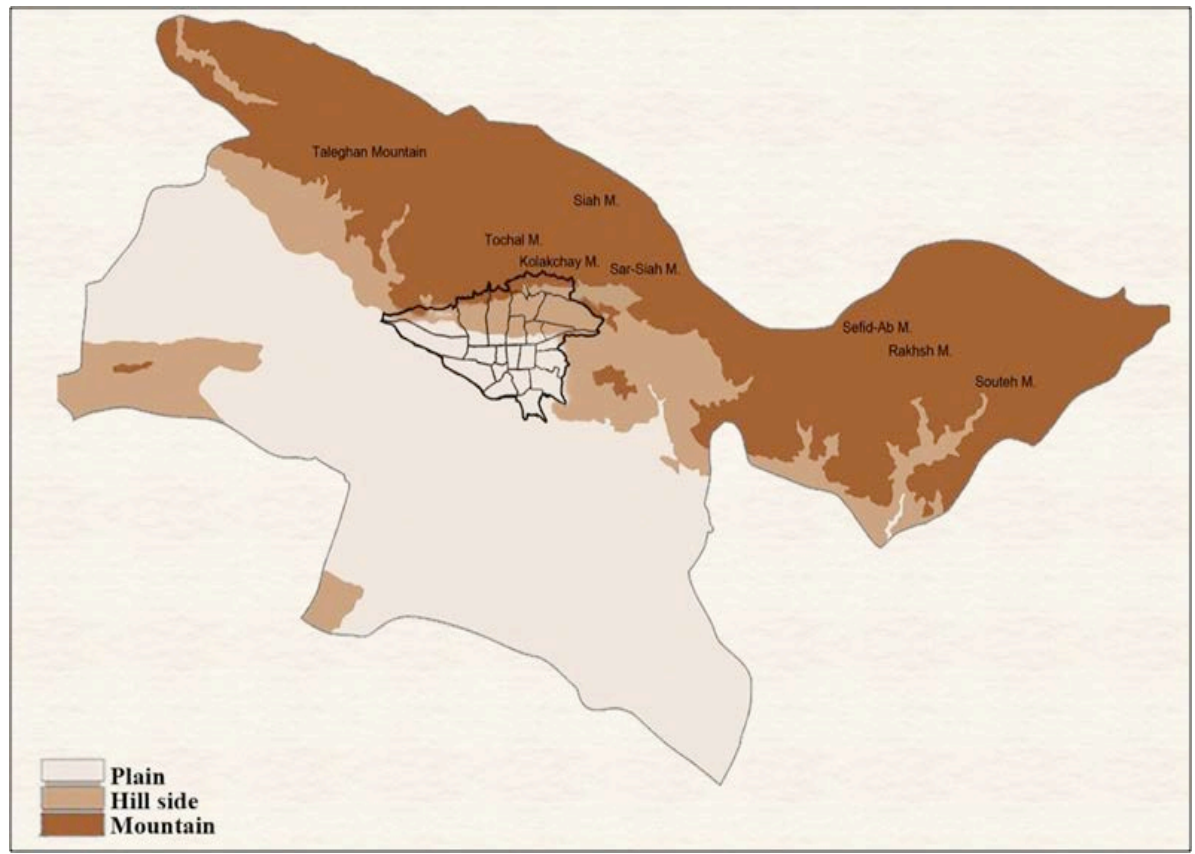

Figure 10. The topography of Tehran Province (2006) (Source: Ref. [41])
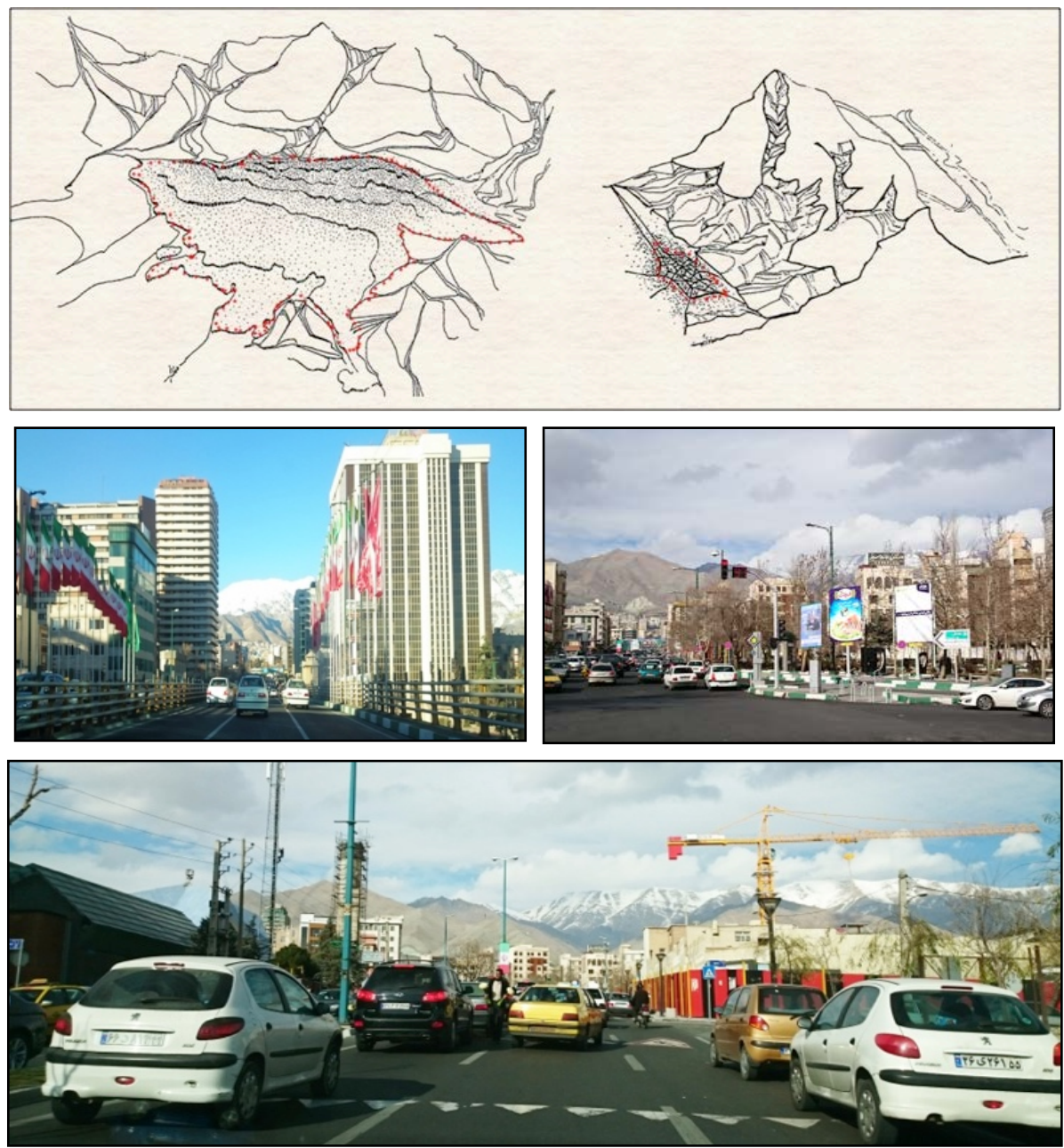

Figure 11. (Top) Tehran is located on the slopes of the Alborz mountain range (located in Northern Tehran); (middle and bottom) views from within the city towards the mountainous area of North Tehran (Source of the base map in the top image: Ref. [8]; Source of the middle and bottom images: Author, 2015) 


\subsection{Flowing Water (Rivers)}

The presence of the Alborz in the northernmost region of Tehran provides appropriate terrain for the formation of rich, perennial, and continuous rivers. Although some rivers have already been turned into polluted canals of water, others have been used as sources of water for industry and agriculture, and as drinking water for Tehranian residents $[8,9,40]$.

Tehran has seven major river-valleys; however, opinion differs as to the total number (for more detail, please see Refs. [8,9,41-43]. Running from the easternmost to the westernmost areas of Tehran, these seven main river-valleys are: Sorkheh Hesar, Dar Abad, Darband, Evin-Darakeh, Farahzad (Pounak), Hesarak, and Kan. Since Tehran slopes in the direction of north to south, the river-valleys are mostly parallel, especially in the northern half of the city, and this topography causes the water to flow from north to south $[8,9,41-44]$. The locations of the seven river-valleys are shown below.

In addition to the seven principal river-valleys, there are other minor river-valleys with shorter lengths or lesser volumes of water. As stated by Behzadfar [9] in 2007, Tehran has 13 river-valleys, of which seven can be described as major. The minor rivers reach the principal rivers at specific points, resulting in an increase in the water volume and the formation of junctions, a phenomenon that gives rise to a synthesis of potentials and problems. The locations of these major and minor rivers, as well as the locations of the confluences, are shown in the following map, while the map also graphically presents the locations of the rivers alongside information about the extent, developments, and expansion of Tehran.

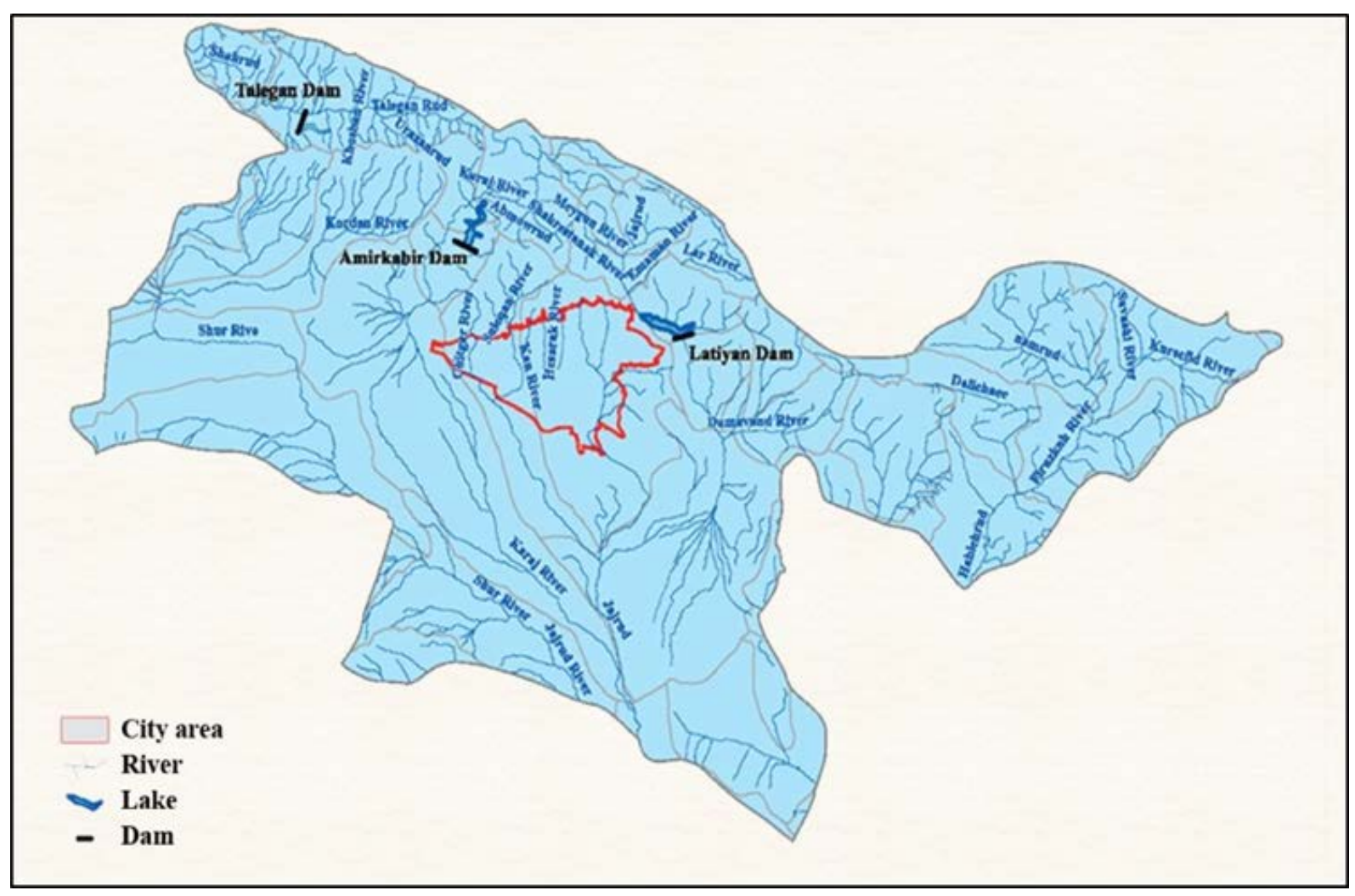

Figure 12. Tehran Province’s watersheds (2006) (Source: Ref. [41]) 


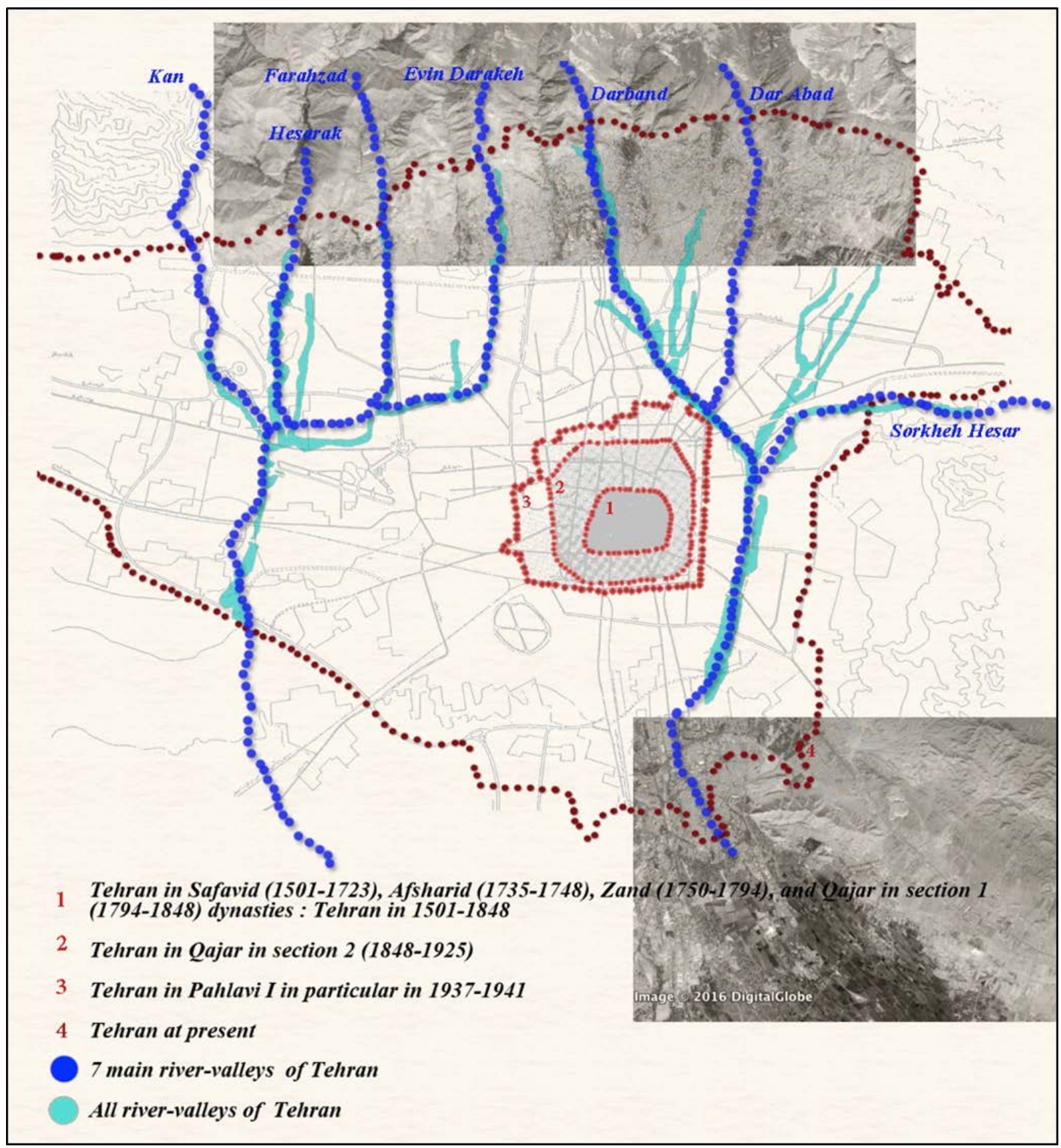

Figure 13. Present-day Tehran and the process of the city's expansion since the Safavid dynasty, and the locations of all river-valleys in Tehran (Source of the base maps: Refs. [8,9,41,42,45])

\subsection{The Identification of Hitherto Implemented Projects in Riverside Neighborhoods}

The co-existence of a unique topography and several rivers in Tehran has resulted in the creation of a combination termed "river-valleys" in the urban and peri-urban context of the city. However, rather than "combination," the term "synthesis" is proposed for the river-valleys because it encompasses the augmentation of their potential, as well as the problems associated with rivers and valleys, if considered as separate entities. As a result of the city's ever-increasing expansion, a significant part of the natural structures and, in particular, the river-valleys that once skirted Tehran has been turned into the city's natural structures.

As explained previously, two of the most important factors from the point of view of Tehranians when selecting a suitable area for the day of Sizdah-be-Dar are access to flowing forms of water such as rivers or streams, and open and flat green spaces incorporating a degree of wildness. The flowing water of Tehran's seven river-valleys seems to provide a suitable context, but the particular topography of valley vs. mountain seems to prevent the possibility of the creation of an ideal context. 
As a result, in order to establish suitable areas in the vicinity of rivers, open and flat green spaces are required. This makes it necessary to identify existing and potential areas that possess the characteristics of vastness, openness, green spaces, and wilderness in the river neighborhoods in the urban and peri-urban areas of Tehran.

In order to identify existing and potential areas with the aforementioned characteristics, it is important to consider current and implemented projects taking place in the seven river-valleys, which include three linear parks and four mountainous recreational areas. The three linear parks, which were created by the Municipality of Tehran, are based on the short lengths of three of the seven river-valleys, and include Park-e-Saheli or Riparian Park on the Dar Abad river-valley in district 1 of Tehran; Nahj-ol-Balagheh Park on the Farahzad river-valley in district 2; and Javanmardan-e-Iran Park on the Kan river-valley in districts 5 and 22.

In addition to these three linear parks, there are four recreational areas in the mountainous and semi-urban parts of four of the river-valleys: Dar Abad, Darband, Evin-Darakeh, and Farahzad. These recreational areas are mostly used for mountaineering, hiking, and other leisure activities by Tehranians as well as tourists. The Dar Abad, Darband, and Evin-Darakeh recreational areas are located in district 1 of Tehran, while Farahzad is in district 2 [4043]. The locations of these projects and some relevant photos are presented in the following figures.
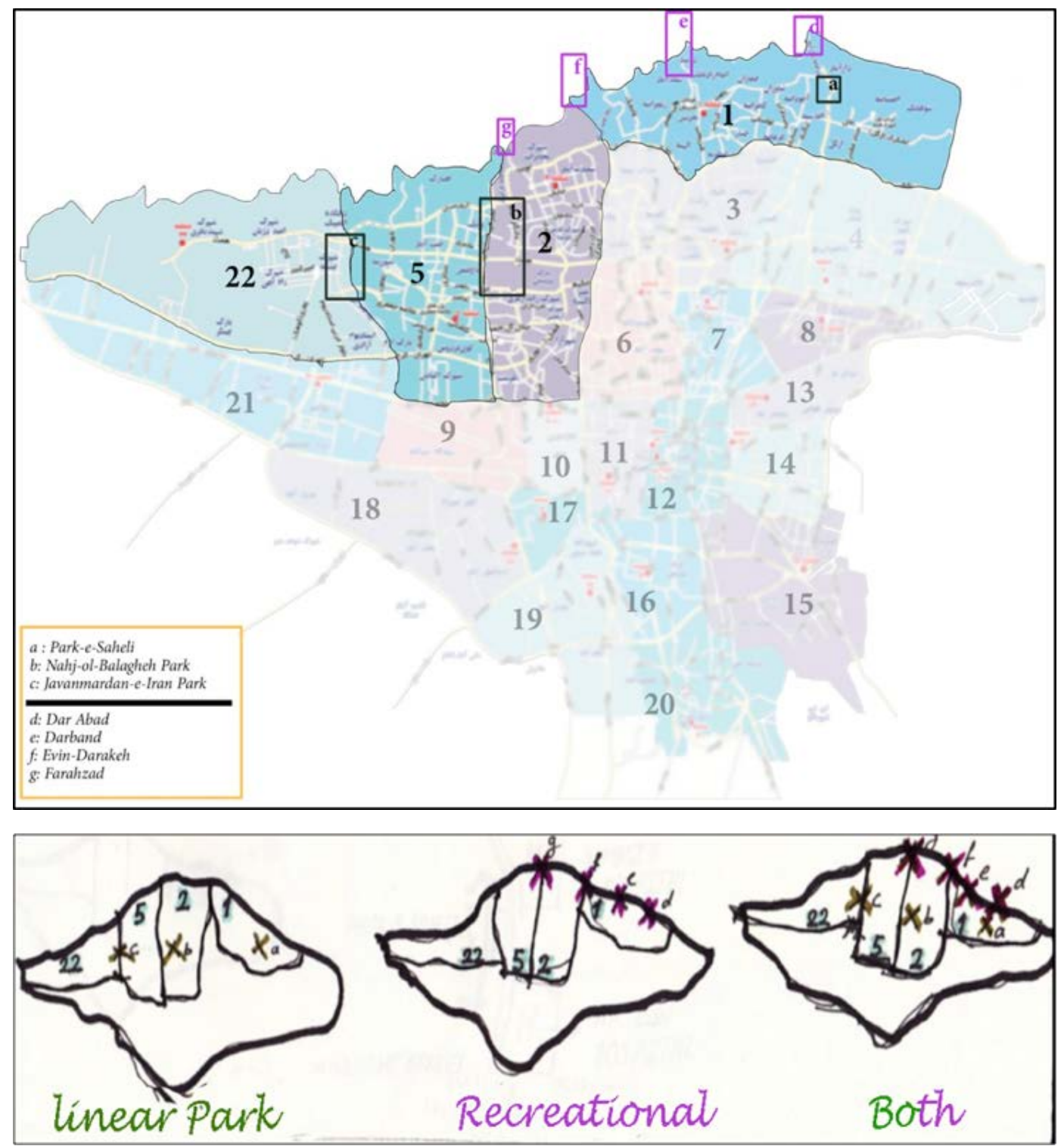

Figure 14. The locations of the three linear parks and four mountainous recreational areas in Tehran (Source of the base map: Ref. [45]; Source of the diagram: Author; 2012) 

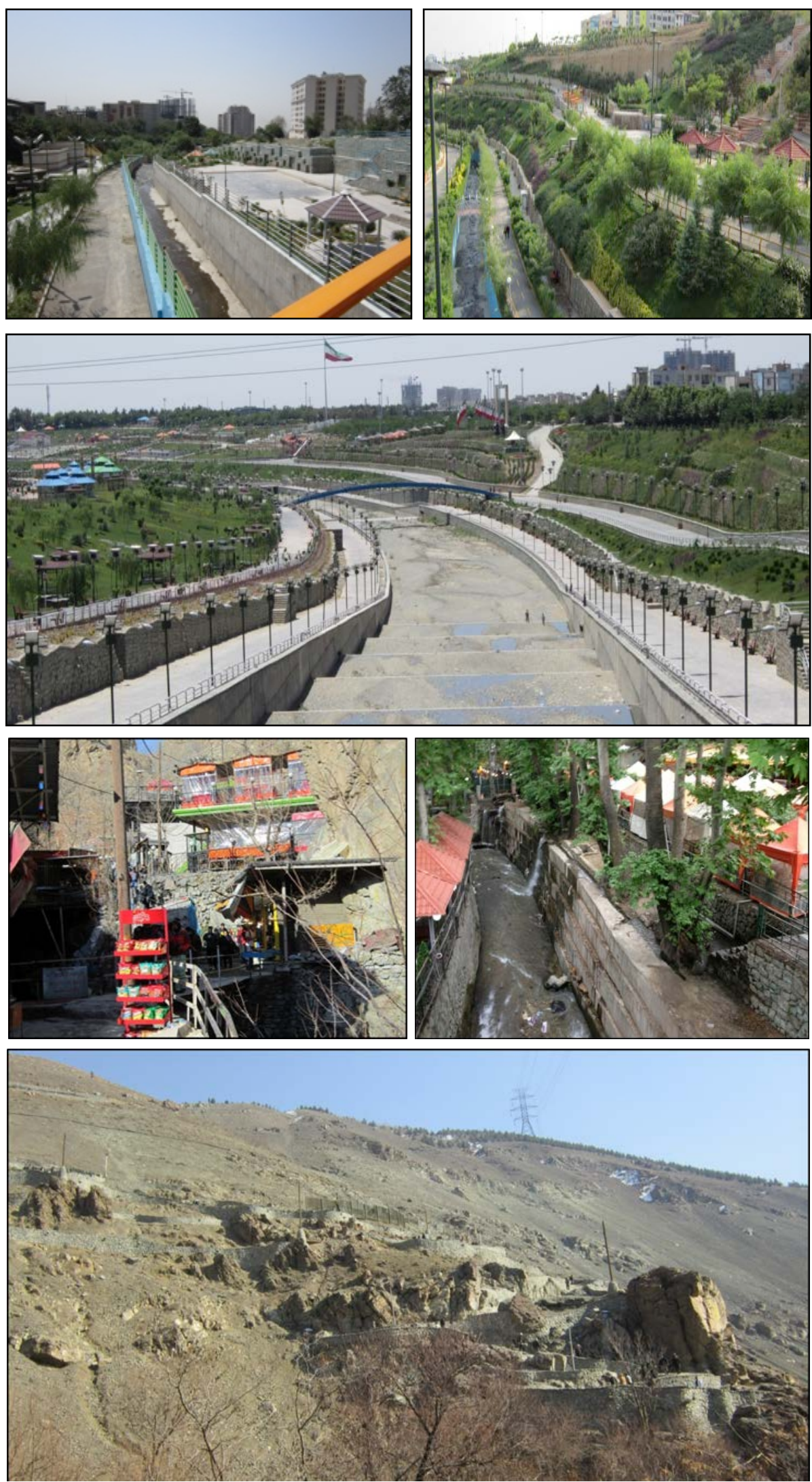

Figure 15. Hitherto implemented projects in the form of linear parks and mountainous areas (2012-2013): the Park-e-Saheli project in Dar Abad, Nahj-ol-Balagheh Park in Farahzad, Javanmardan-e-Iran Park in Kan, and the Darband, Evin-Darakeh, and Dar Abad mountainous recreational areas (Source: Author, 2012-2013) 


\subsection{In the Implemented Projects, Are There Any Existing Areas with Access to Flowing Water and Open, Flat, and Green Wilderness Spaces?}

Although both types of implemented projects have access to flowing water (as the most important factor for Sizdah-be-Dar), none of the areas have green spaces that are either open or vast (the second most important factor); as a result, neither is considered suitable by Tehranians for the rituals associated with Sizdah-be-Dar. Over $90 \%$ of the interviewees in this research stated that the mountainous recreational areas and linear parks were not suitable for celebratory days such as Sizdah-be-Dar that require specific customs and traditions.

As the interviewees explained, in addition to making it possible to follow the tradition of tying pieces of grass together, the existence of flat and open green spaces allows each family to place a blanket or cloth on the ground and sit with other family members for the whole day, while maintaining the necessary space and privacy from other families sitting close by. The lack of a suitable area close to the rivers necessitates the consideration of potential areas for these special days, and this point is studied in detail in the following section.

The implemented projects, whether mountainous recreational areas or linear parks, do not feature open and flat green spaces; in other words, the issue of a pronounced height difference in the executed projects results in a lack of openness and vastness, and none of these areas are considered suitable for the rituals required for specific days such as Sizdah-be-Dar. As stated by the majority of interviewees, the height difference in the linear parks creates the perception of being in a deep valley. There are two reasons for this. First, the highest points of these parks and the main streets of local neighborhoods are at the same height, so pedestrians in the main streets can see that the parks are located at a certain depth. Second, the height difference between the horizontal layers is high, compared to the width, which creates a feeling of enclosure and high depth $[40,42,46]$.

In the mountainous recreational areas, hillside paths that move towards the top of the mountain create an impression of a height difference. There are two reasons for this. First, the starting points of the areas are usually located at the bottom, and the direction of movement is towards the top of the mountain, so the summits and the upward paths towards them are mostly visible from the starting points. Second, the contextual materials of the rocks used in the path walls enhance the feeling that one is climbing a mountain. The majority of interviewees in the mountainous areas explained that organic-shaped paths with rocky walls, in combination with the slopes of the mountains of northern Tehran, create the feeling of being present in a mountainous area.
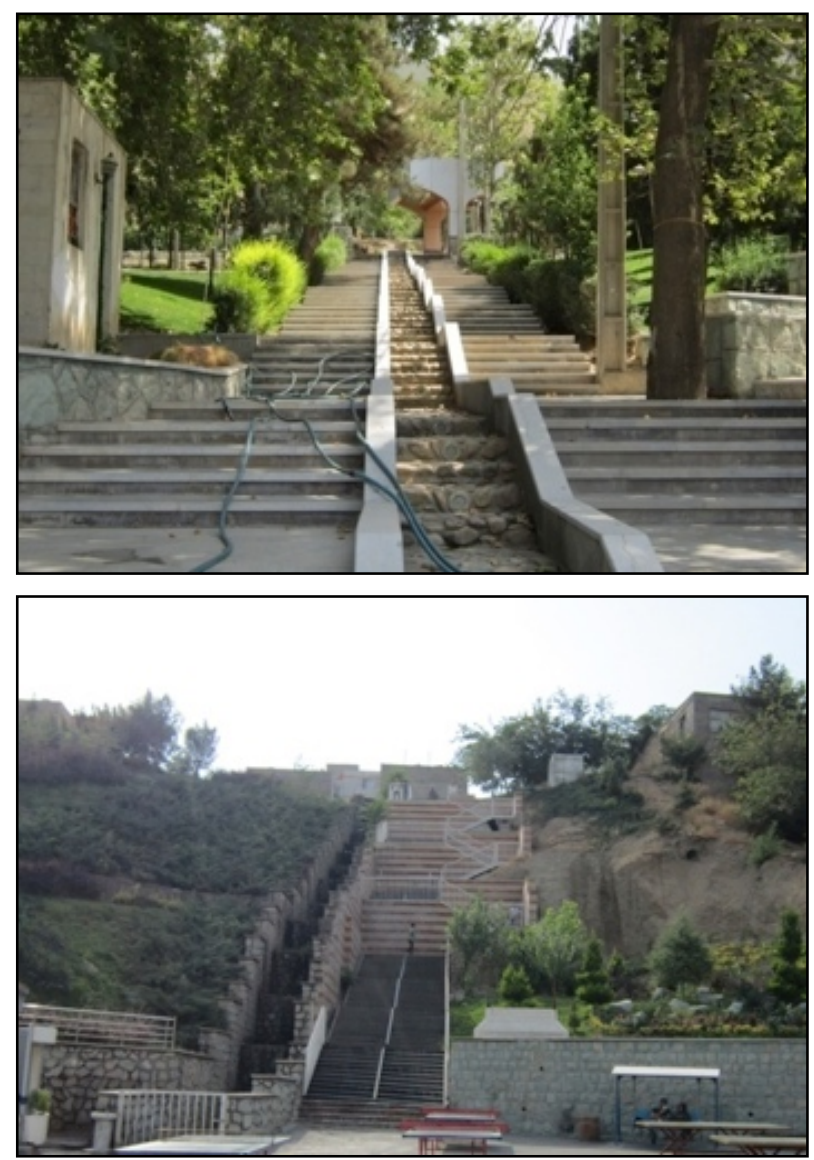

Figure 16. Examples of stairs at the main entrance from the main street level. (Left) Park-e-Saheli (2013); (right) Nahj-ol-Balagheh Park (2012) (Source: Author, 2012-2013)
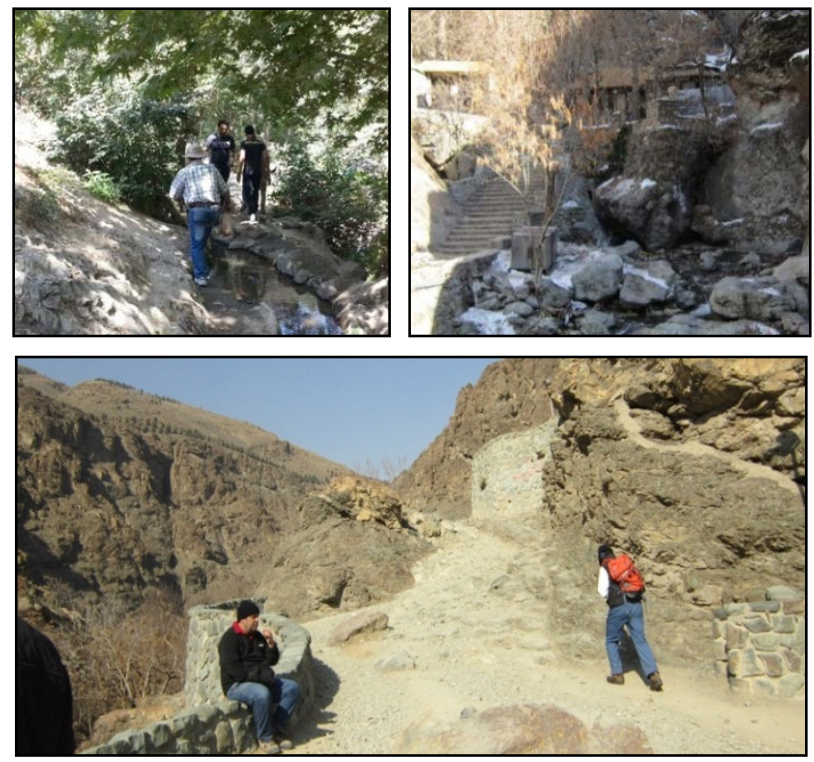

Figure 17. Rocky, organic, and sinuous mountain paths. (Top-left) Evin-Darakeh (2012); (top-right) Darband (2013); (bottom) Dar Abad (2013) (Source: Author, 2012-2013) 
The lack of open and flat green spaces in the vicinity of Tehran's rivers is also evident when one examines the spatial structure of the city, and via Google Maps. The point is demonstrated in the following maps for further clarification. The lack of the co-existence of flowing water and open and flat green spaces in the hitherto implemented projects makes it necessary to identify potential areas that could be developed and allocated to enable the rituals that are performed on celebratory days such as Sizdah-be-Dar. This will be further explained in the next section of this paper.
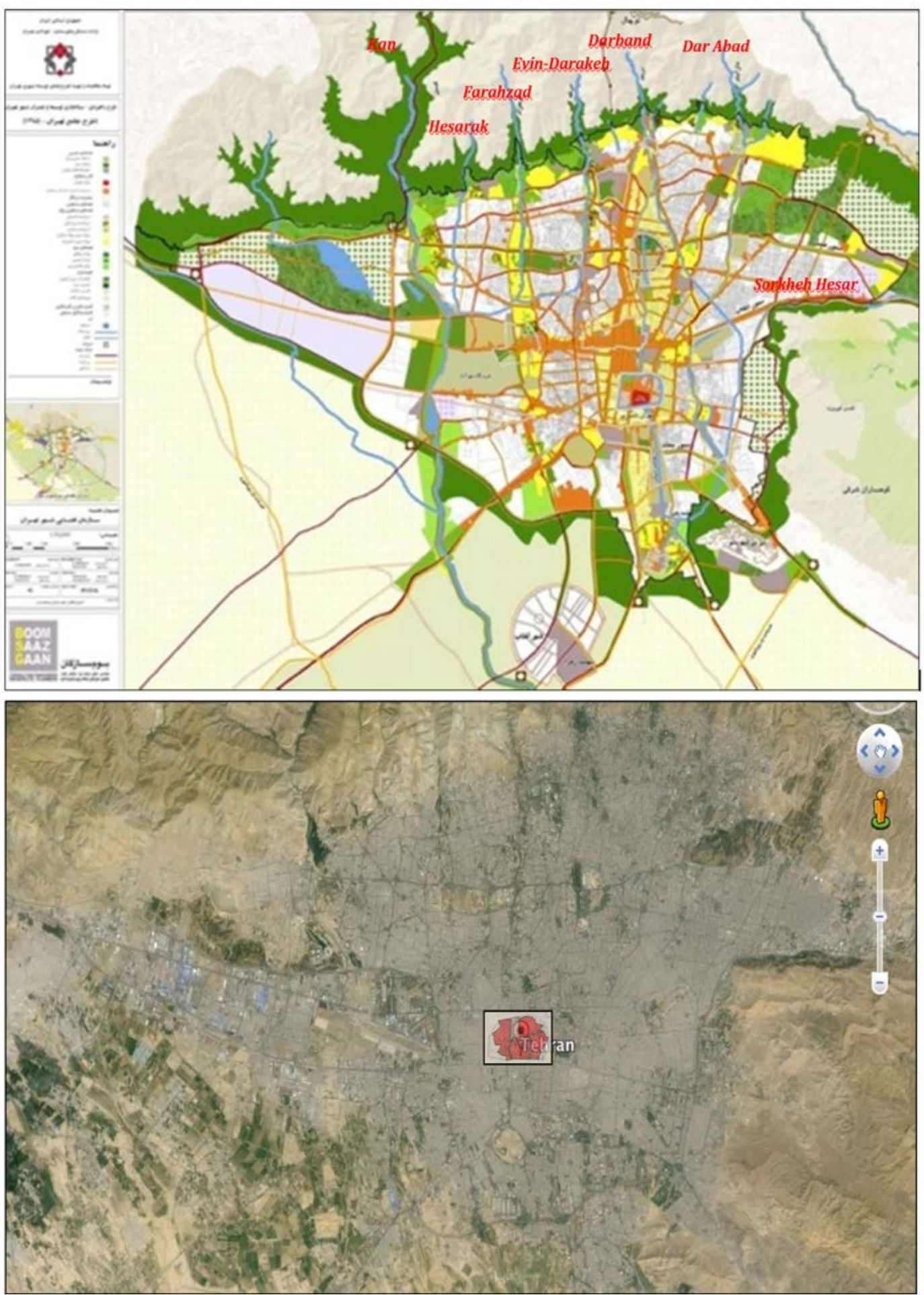

Figure 18. (Top) The location of the seven river-valleys in the spatial structure of Tehran; (bottom) Google Map view of Tehran as an ever-developing and -expanding city. and the lack of open and vast green wildernesses in the hitherto implemented projects in the rivers' neighborhoods. (In red: Tehran as a ramparted city with four neighborhoods at the time of the Safavid, Afsharid, and Zand dynasties.) (Source of the top image: Ref. [43]; Source of the bottom image: Refs. [8,9,47]) 


\subsection{Where are some Suitable Areas with Access to} Flowing Water, Featuring Open, Flat, and Green Wildernesses in Urban and Peri-Urban Areas of Tehran?

When identifying the location of suitable areas in the vicinity of Tehran's rivers, it should be remembered that the height difference between the northernmost and southernmost areas of Tehran is around one kilometer and, as a result, the southern areas of the city are home to more flat areas. Furthermore, due to the city's topography and north-south slope, some rivers become jointed and create confluences; two of the main confluences are shown in the following images. As these images make clear, suitable areas that are open, flat, and green, with access to flowing water, are best searched for in the southernmost urban and peri-urban areas of Tehran that are located in the vicinity of the two aforementioned rivers.

In the northernmost areas of Tehran, in contrast, the green spaces are not home to open and flat areas, as shown in the following images. The reason for this, as explained previously, is the presence of the Alborz mountain range to the north of Tehran, making it very difficult to find and develop suitable spaces for the celebration of Sizdah-be-Dar. It can therefore be summarized that, in contemporary Tehran, the main riverside areas that are best able to strengthen, develop and revive the rites associated with specific days that have been passed down to the present from the ancient world are in the southern areas of the city.

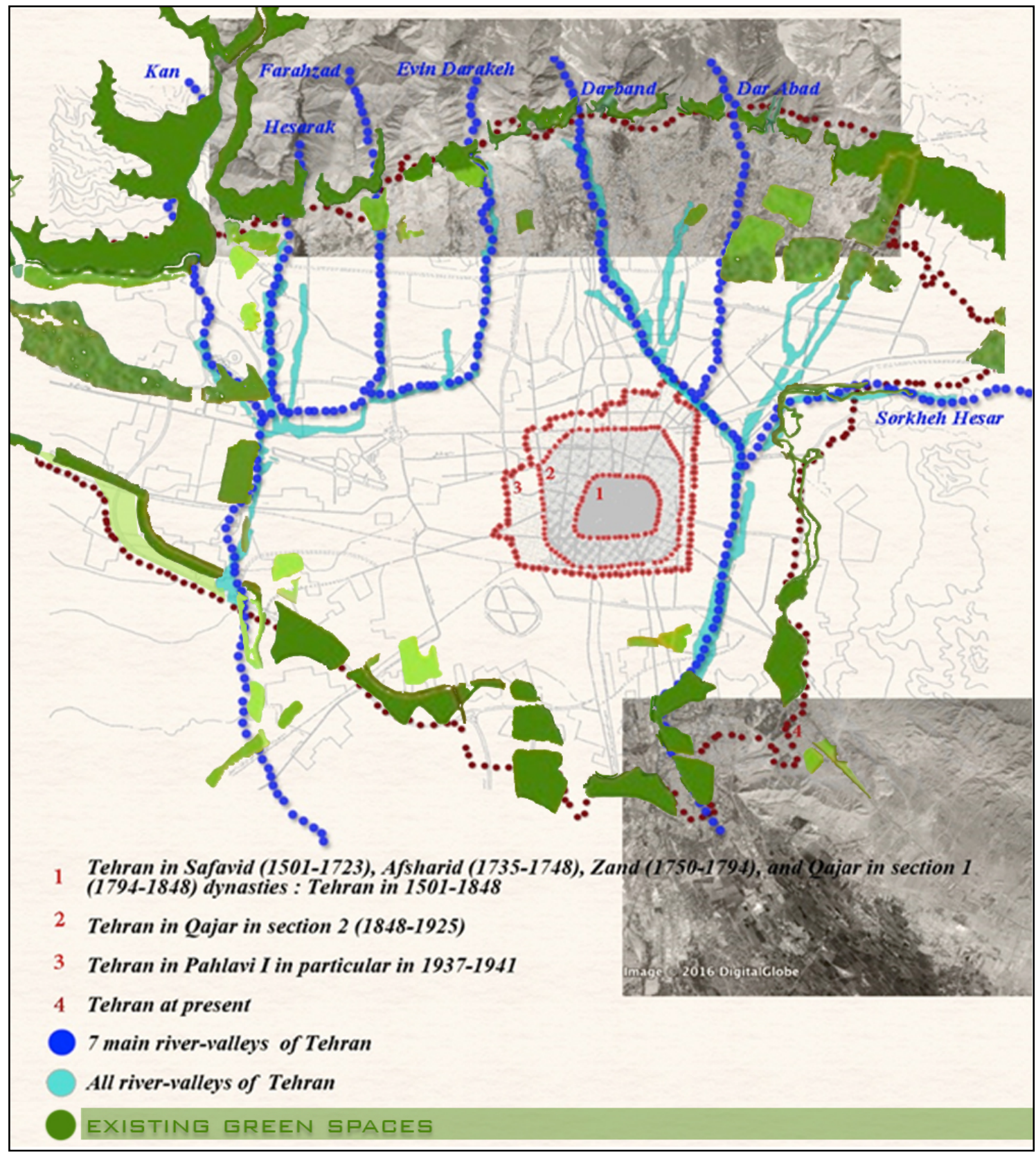




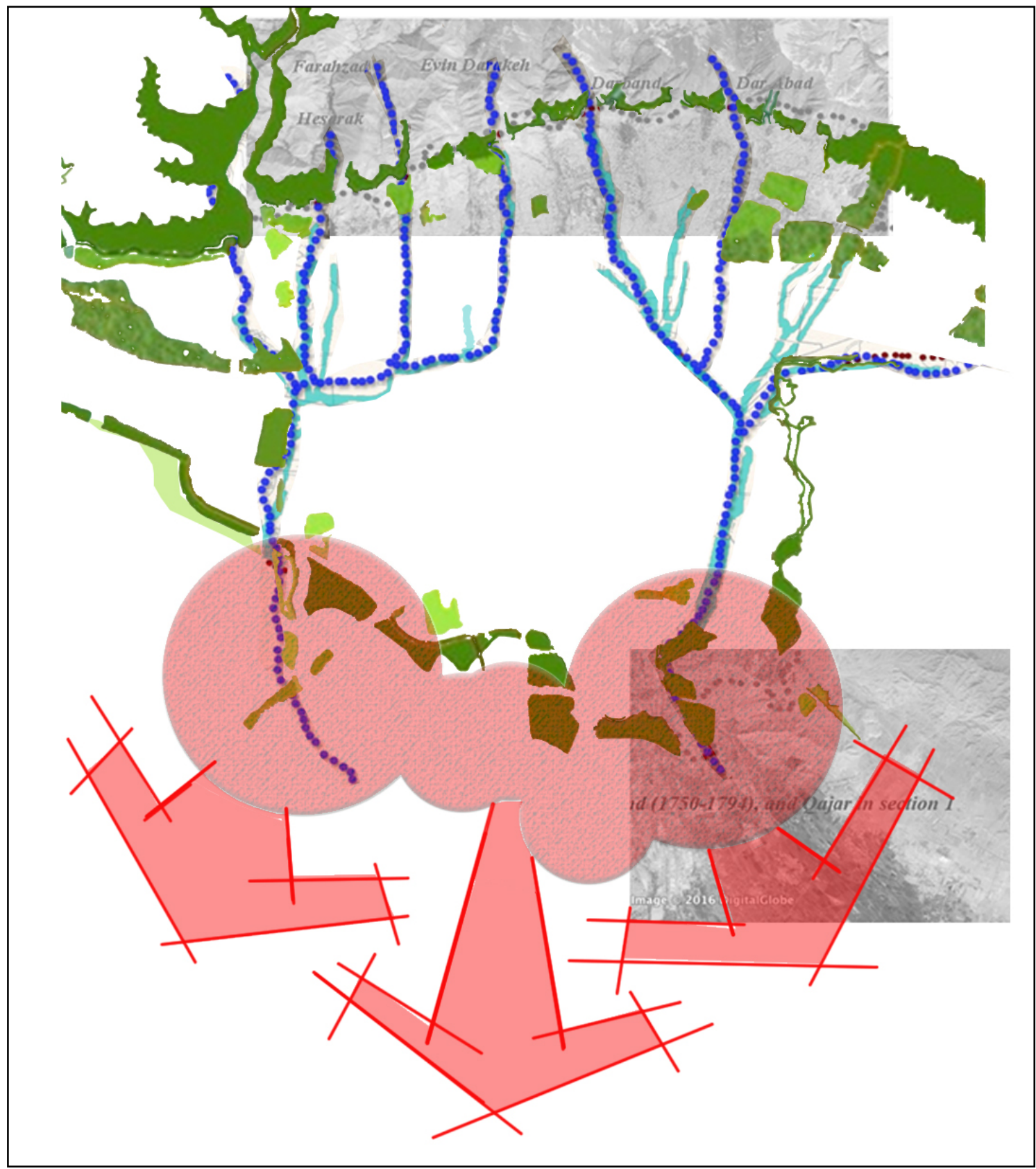

Figure 19. (Top) Location of the existing green spaces (in the background: rivers and mountainous areas of Tehran, and semi-mountainous areas in southeast Tehran); (bottom) location of potentially suitable green spaces (open, flat, and green, with access to flowing water) and the direction of potential development (Source of the diagrams: Author, 2018; Source of the base maps: Refs. [8,9,41-45])

It should be noted that, in southeast Tehran, and particularly close to one of the two aforementioned rivers that run from the north to the south of the city, known as Darband, there is a semi-mountainous area, the Bibi Shahr Banoo Mountain [8,9,40]. The Darband river-valley starts from the mountainous areas of north Tehran and continues to the plain lands and then the deserts in the southeast of the city. Although the northern part of this river is recognized as a mountainous recreational area, there are no projects to create a similar area in the semi-mountainous area of southeast Tehran. Furthermore, the peri-urban areas of southeast Tehran are home to some of the biggest parks in the city; however, at present, the Darband river-valley has not been chosen as the site of a park.

The location of the Bibi Shahr Banoo semi-mountainous area offers a suitable boundary line for the development of suitable green spaces in the southeast direction, while the distance between the river and this mountainous area allows for a certain amount of development. In addition to the Bibi Shahr Banoo, there are some big parks in the city and undeveloped pieces of land; the locations of these parks and the direction of possible development for these green spaces are outlined in the following diagram. 

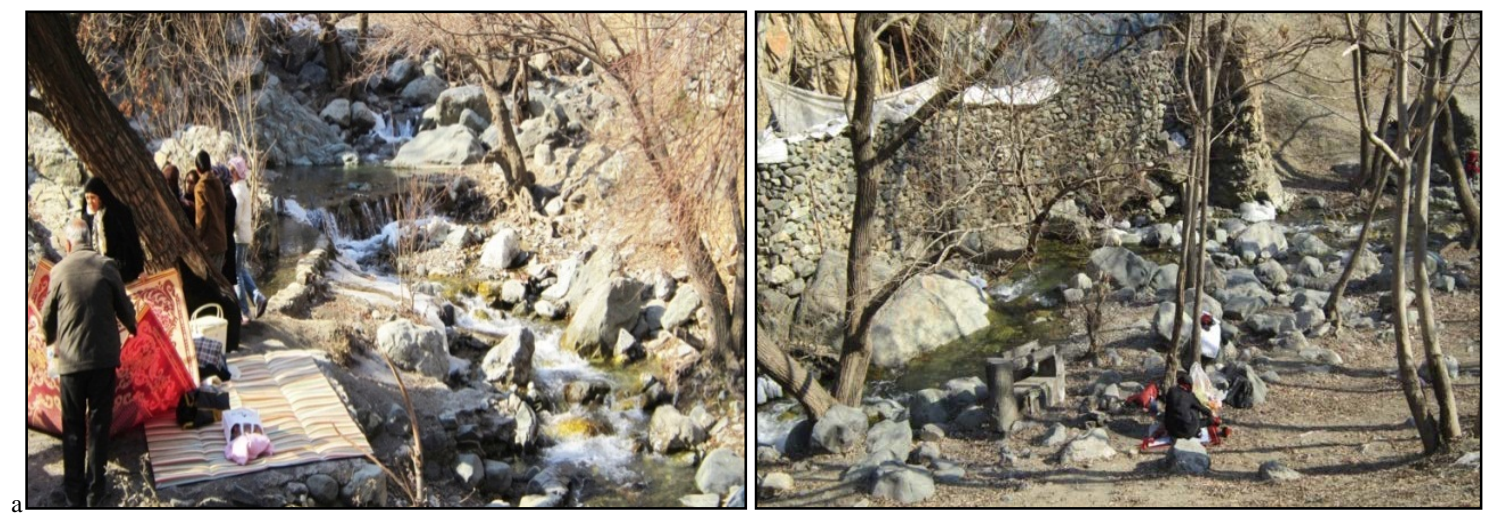

Figure 20. The presence of wilderness but absence of open, flat, and green spaces in the mountainous areas of North Tehran: the example of the Dar Abad mountainous area (Source: Author, 2013)

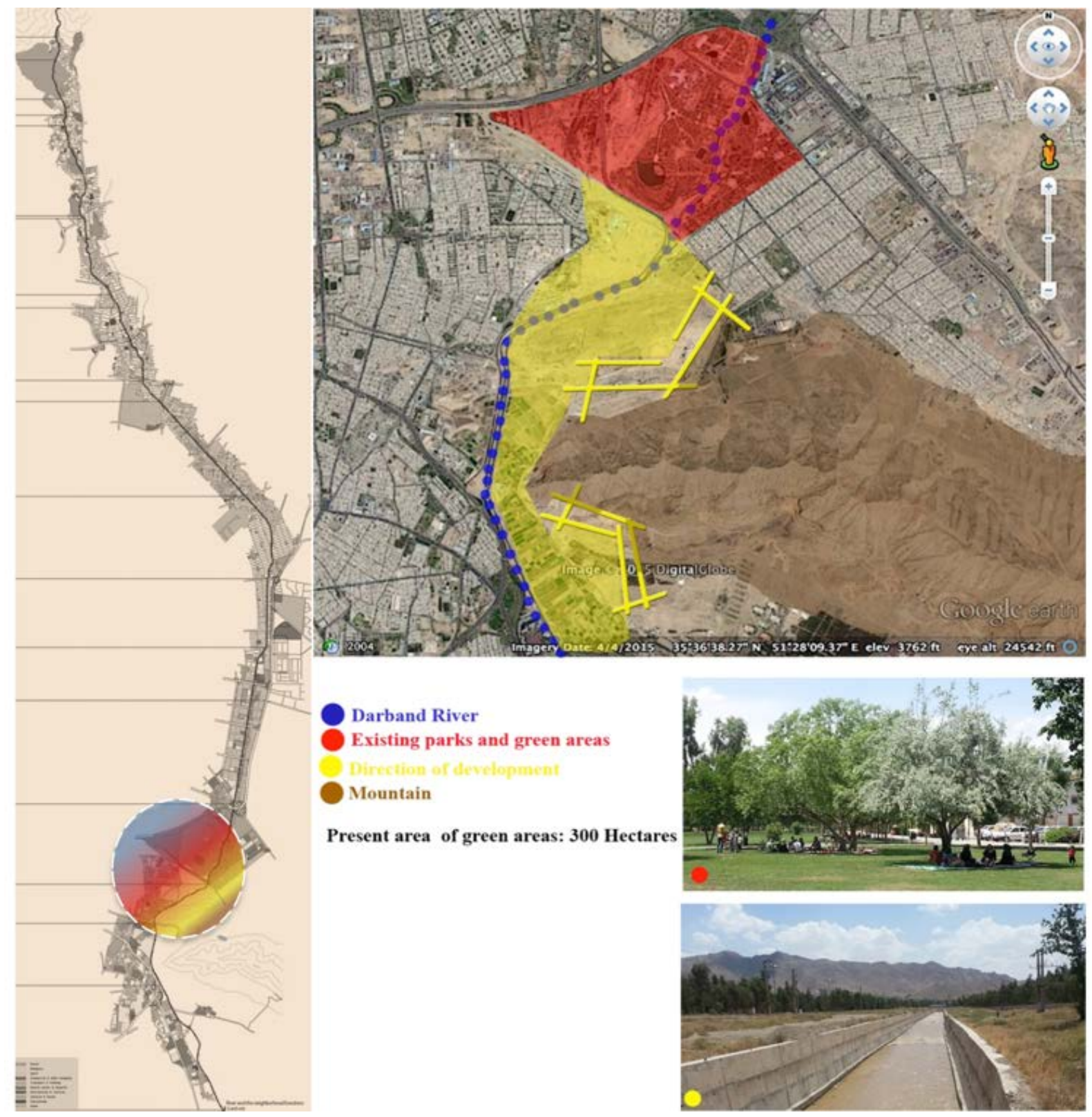

Figure 21. Potential and direction for the development of suitable green spaces in the vicinity of the Darband river in southeast Tehran (Source of base map at top-right: Ref. [47]; Source of photos, map and diagram: Author, 2016) 


\subsection{An Additional Point}

As a final point, it should be noted that, to ensure that the river has pure and high-quality water, it is necessary to conduct a comprehensive design and planning process for the whole length of the river in the urban region. In other words, such continuity and purity will only be possible if the whole length of the river and its neighborhoods are studied in detail. One reason for the high levels of water pollution in present-day Tehran is the implementation of projects on certain parts of the river. Indeed, rivers typically pass through polluted areas and covered canals in the urban regions, and thus sometimes carry various types of waste. These waste materials accumulate along the river path from the northernmost to the southernmost areas, which gives rise to particular problems in the southern parts of Tehran. As a result, in order to create suitable areas for rituals that are conducted on certain celebratory days in the south of Tehran, it is essential that the authorities engage in a comprehensive project that ensures water continuity and purity and encompasses the whole length of the river, from the north to the south of the city. The current accumulation of pollution in the north-south direction is an issue in the Darband river, as shown in the following images:

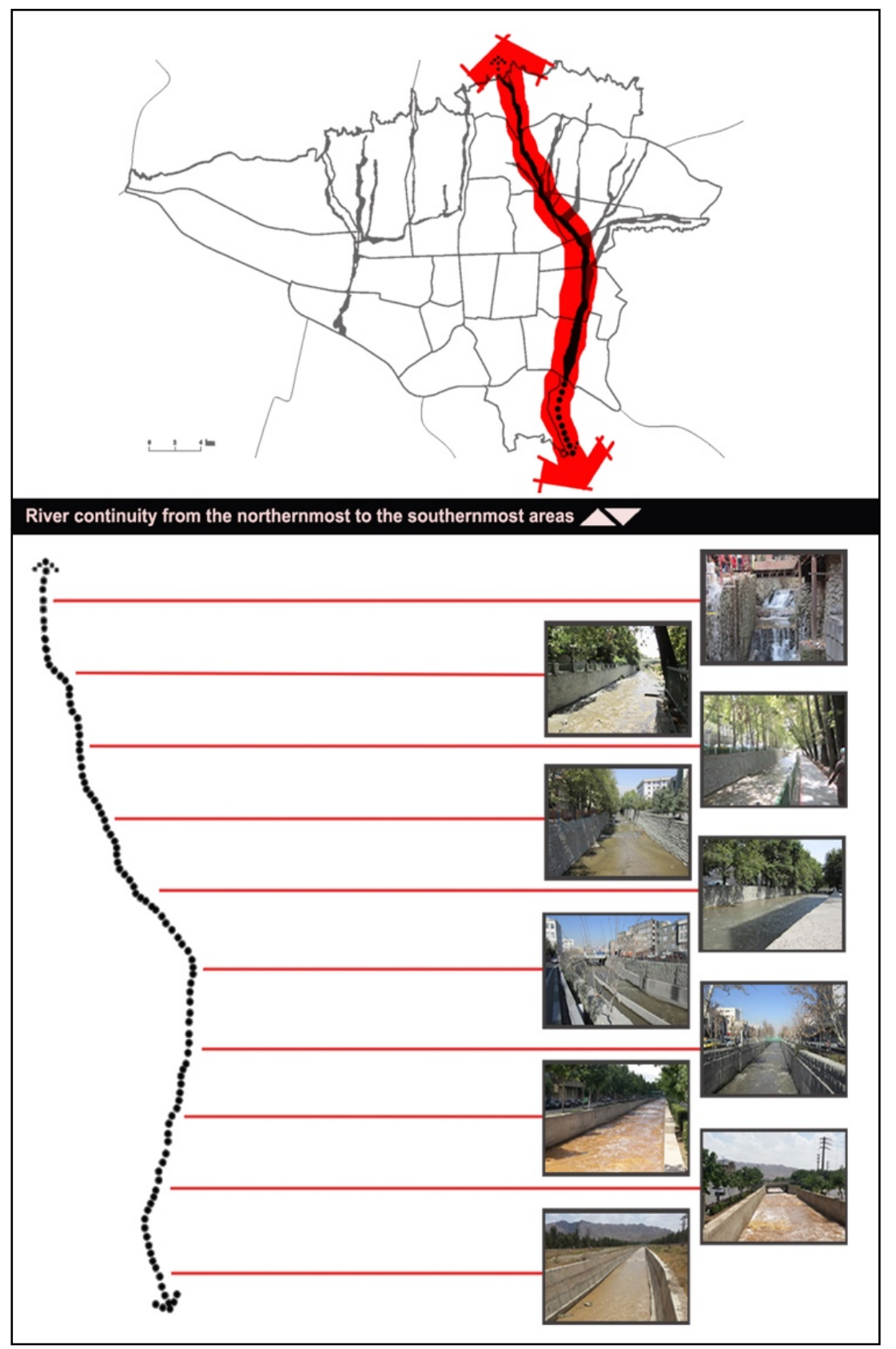

Figure 22. River continuity and accumulation of waste, from the northernmost to the southernmost areas of Tehran, occurring due to the absence of a system to improve the quality of water in the river (Source: Author, 2016) 


\section{Conclusions}

Tehran has been the capital of Iran since 1794. Since that time, the population of the city and the wider province has consistently increased. As the result of the city's expansion, in particular since it became the capital, large areas of open and unconstructed land, as well as the green spaces of the peri-urban areas, have been converted into urban lands for construction, and a significant part of the natural structures on the outskirts of the city have been changed into urban neighborhoods [7-9,40]. This paper has looked at river-valleys, one of these urban natural structures, in order to redefine them as an integrated natural structure within the urban context of Tehran, and the rituals performed by Tehranians during specific celebratory days.

As outlined in the first part of this paper, Tehranians interact with nature as they engage in particular customs and traditions associated with specific days and events. While some of these traditions are still alive, others have all but disappeared. This paper has mainly looked at the Persian New Year and its water-based rituals, including Norouz and Mitrakan (Mehregan), the few days that occur before Norouz, Norouz and Haft Sin; Small Norouz, Big Norouz, and Ab Pashan; and the 13th day of Norouz: Ab Rizgan, Tirgan, and Sizdah-be-Dar. The local tendency to keep these customs and traditions alive, such as the practice of placing sabzeh in flowing water and tying together two pieces of grass on the day of Sizdah-be-Dar, and interviewees' interest in and desire to revive disappearing or forgotten rituals such as Ab Pashan and Ab Rizgan, were revealed in the interviews conducted in the course of this research.

The second part of this paper investigated the urban and peri-urban areas of Tehran that could be turned into suitable green spaces for celebratory days, particularly those associated with the need for access to flowing water, and open and flat green spaces. In order find such areas, it was imperative to study hitherto implemented projects in the vicinity of Tehran's rivers. So far, three linear parks and four mountainous recreational areas have been implemented in specific parts of riverside neighborhoods, but none of these projects have been identified as Tehranians' preferred areas to conduct the two aforementioned traditions because they do not feature open and flat green spaces.

In addition, the second part of this paper looked at potential areas that could be designed and developed to make them suitable for the rituals of specific days such as Sidah-be-Dar. Such areas are mainly located in the south of Tehran and in the neighborhood of two rivers that pass the urban and peri-urban areas of Tehran, moving from north to south. These two rivers are actually the confluences of some of the main river-valleys of the city. The height difference between the north and south of Tehran is at most around one kilometer; therefore, the best option for the creation of open and flat green spaces would be to explore the southern areas of urban and peri-urban Tehran.

As a final word, it should be mentioned that this paper opens a platform for discussion on the socio-cultural aspect of sustainability by investigating aspects of the rituals of specific celebratory days that have begun to disappear, particularly the nature-based festivals associated with the Persian New Year. The environmental aspect of this issue has been investigated as an affiliated and interdependent aspect. Future research would do well to examine the relationship between socio-cultural and other aspects of sustainability. In a comprehensive sense, all aspects of sustainability need to be considered in parallel ways and by different scholars in various fields of study. This would thus result in achieving sustainability in the full sense of the concept.

Furthermore, this paper also opens the debate for researchers in the fields of history and archeology concerning rituals and traditions that can be traced to the ancient world, and their relation to the natural structures of cities. Decoding the mysteries of past generations through future archeological, historical, and ethnographic investigations could reveal the aspects that have been chronologically disregarded, specifically in terms of the human-nature relationship, but which have the potential to be revived in order to reconstruct this relationship in a mutually supportive manner.

\section{REFERENCES}

[1] H. Razi, The Religion and Culture of Ancient Iran, Tehran, Sokhan, 2003.

[2] H. Razi, Ancient Iranian Festivals: Norouz, Abpashan, Abrizgan with the Religious Ceremonies and Customs of Zarathushtrian/ Parses, Tehran, Behjat, 2004.

[3] R. N. S. Clair, W. Song, The Many Layers of Culture within Each City, a Theory of Cultural Geography. Lewiston, N.Y., Edwin Mellen Press, 2009.

[4] A. Zarrinkoub, Becoming Familiar with Literary Criticism, $8^{\text {th }}$ ed., Tehran, Sokhan, 2009.

[5] F. Joneidi, Zarvan, Chronology in Ancient Iran, Tehran, Boniad e Neishabour, 1979.

[6] F. Sheikh Farshi, Anahita in Ancient Iranian Beliefs, Tehran, Horoufieh Publishing, 2002.

[7] A. Anvar, Preface, In: Norouzi Talab, H.R. (eds.) Tehran (Past \& Present): The Heritage of Old Tehran, Tehran, Yassavoli Publications, 2011, 12-40.

[8] M. Hamidi et al., Structure of Tehran, Tehran, Technical and Engineering Consulting Organization of Tehran, 1997.

[9] M. Behzadfar, Case-Study: Tehran, The Identity of City, Tehran, Nashr-e-Shahr, 2007.

[10] A. Banimasoud, Iranian Contemporary Architecture, 2nd ed., 
Tehran, Honar-e-Memari-e-Gharn, 2009.

[11] ISNA News, The Proportion of the Capital (Tehran) in Population of Iran, 2014, Online available from https://www.isna.ir/news/93021007033/56

[12] Statistical Centre of Iran, General Information of Tehran Province in 2017, Statistical Centre of Iran - Management and Planning Organization, 2017, Online available from http://www.mpo-es.ir/Dorsapax/userfiles/Sub1/g_sarshoma ri95.pdf

[13] L. Groat, D. Wang, Architectural Research Methods, New York, Wiley, 2002.

[14] F. A. Finn, Getting a PhD: An Action Plan to Help Manage Your Research, Your Supervisor and Your Project, London, Routledge, 2005.

[15] J. Gehl, B. Svarre, How to Study Public Life, Washington, Island Press, 2013.

[16] A. Galletta, Mastering the Semi-structured Interview and beyond from Research Design to Analysis and Publication. New York and London, New York University Press, 2013.

[17] M. W. Waters, Ancient Persia: a Concise History of the Achaemenid Empire, 550-330 BCE, New York, Cambridge University Press, 2014.

[18] E. L. Daniel, A. A. Mahdi, Culture and Customs of Iran, Westport, Conn. London, Greenwood Press, 2006.

[19] C. Massoudi, Land of the Turquoise Mountains: Journeys Across Iran, London, I. B. Tauris \& Co, 2014.

[20] J. E. Campo, Encyclopedia of World Religions: Encyclopedia of Islam, New York, Facts on File, 2009.

[21] K. Highbaugh, The Esoteric Codex: Numerology, Lulu.com, 2015.

[22] G. Mirafzali (Andalibi), The Mystery of the Haft-Seen, $2^{\text {nd }}$ ed, USA, Ketab Corp, 2009.

[23] Y. Khani, Sizdah-be-Dar: The nature Day in Iran, Mehr News Agency, 2016, Online available from http://www.me hrnews.com/news/2525842

[24] Mehr News Agency, Sizdah-be-Dar in Iran, Mehr News Agency, 2016, Online available from http://www.mehrnew s.com/news/2525842

[25] E. Maroozi, The customs of Sizdah-be-Dar. Mehr-e-Mihan Group: An Iranian Culture Media, 2013, Online available from http://www.mehremihan.ir/iranian-traditions/841

[26] G. Rahimi, Putting Sabzeh in the flowing water in Sizdah-be-Dar in Iran, Panoramio, 2015, Online available from http://www.panoramio.com/photo/50573913

[27] M. Bahar, Queries in Iran's Culture, Tehran, Fekr e Rooz, 1994.

[28] Lonely Planet, Lonely Planet: Middle East Phrasebook, Australia, Lonely Planet Publications, 2007.

[29] D. A. Mackenzie, Myths of Babylonia and Assyria, Białobrzegi, Poland, Masterlab, 2014.

[30] A. Ghorashi, Water and Mountain in the Indo-Iranian
Mythology: an Introduction to the Indo-European Toponymy, $2^{\text {nd }}$ ed., Tehran, Hermes, 2010.

[31] P. Nabarz, P. (ed.), Anahita: Ancient Persian Goddess and Zoroastrian Yazata, London, BM Avalonia, 2013.

[32] P. Nabarz, The Mysteries of Mithras: The Pagan Belief That Shaped the Christian World, Rochester, Vermont, Inner Traditions, 2005.

[33] S. Gaviri, Anahita in the Ancient Iranian Mythology, $3^{\text {rd }}$ ed, Tehran, Ghoghnous, 2006.

[34] Javanfa Group, Sizdah-be-Dar in Old Time, Painting by Fathollah Gholar, Javanfa Group, 2015, Online available from http://www.javanfa.ir/post/19864/94

[35] P. Shahsanaei, The day of Nature in Isfahan, ISNA News Agency, 2018, Online available from https://www.isna.ir/p hoto/97011302678

[36] Zamzar Group, The day of Sizdah-be-Dar, Zamzar Group, 2016, Online available from http://www.zamzar.ir/28134/

[37] Qazvini, Zakaria Ben Mohhamd Ben Mahmud, Issues of Lands and News of People (آثار البلاد و اخبار العباد) Translated from Arabic to Persian by J. Mirza Qajar, and Revised and Complemented by M.H. Mohaddes (1994), Tehran, Amir Kabir, 1275,

[38] Beytooteh Group, The History of Iran, Beytooteh Group the Section of Art and Culture, 2014, Online available from http://www.beytoote.com/art/negah-gozashte/iran-history.ht $\mathrm{ml}$

[39] S. Sadvandian, The Story of Modernity in Iran, Institute for Iranian Contemporary Historical Studies - The Section about Transformation of Tehran, 2014, Online available from http://www.iichs.ir/News-1/(1)

[40] Municipality of Tehran, Living in Tehran: About Tehran, Municipality of Tehran, 2015, Online available from http://www.tehran.ir/Default.aspx?tabid=117

[41] Tehran Municipality Information \& Communication Technology Organization, Atlas of Tehran Metropolis, Tehran, Tehran Municipality Information \& Communication Technology Organization, 2011.

[42] Municipality of Tehran, Living in Tehran: the Environment, 2011, Online available from http://www.tehran.ir/Default.a spx?tabid $=118$

[43] Ministry of Roads and Urban Development of Iran and Urbanism and Architecture Committee (Ministry of Housing and Urban Development), Strategic-Structural Plan of Tehran and the Development (Comprehensive Plan of Tehran-2007), 2007, Online available from http://shahrsazi.tehran.ir/Portals/0/Documents/sanad\%20ja me1386.pdf

[44] Tehran Disaster Mitigation and Management Organization (TDMMO) (affiliated to Municipality of Tehran), Mountaineering Paths of the North Tehran, 2014, Online available from http://tdmmo.tehran.ir/Default.aspx?tabid=1 46\&ArticleCategory $=156 \&$ smid $=531$

[45] Municipality of Tehran, The Map of 22 Districts of Tehran, 2013, Online available from http://region13.tehran.ir/portal s/0/Test/tehran-map-naghshe-iran-mantaghe-shahrdary.png 
[46] M. Carmona et al., Public Places-Urban Spaces: The Dimensions of Urban Design, Oxford, Architectural Press, 2003.

[47] Google Maps, Tehran, Iran (detail) Map, Google Maps, 2016, Online available fromhttps://www.google.co.uk/maps/@35 .6835556,51.3790918,11z

[48] J. Teng, Musket, Map and Money: How Military Technology Shaped Geopolitics and Economics, London, Versita, 2013.

[49] A. A. Dehkhoda, Dehkhoda Encyclopedic Dictionary of Persian Language, Tehran, University of Tehran in collaboration with Dehkhoda Lexicon Institute \& International Center for Persian Studies, 1998. 